DEMOGRAPHIC RESEARCH

VOLUME 38, ARTICLE 50, PAGES 1535-1576 PUBLISHED 3 MAY 2018

http://www.demographic-research.org/Volumes/Vol38/50/

DOI: 10.4054/DemRes.2018.38.50

Research Article

\title{
A regional perspective on the economic determinants of urban transition in $19^{\text {th }}$-century France
}

\section{Philippe Bocquier}

\section{Sandra Brée}

(C) 2018 Philippe Bocquier \& Sandra Brée.

This open-access work is published under the terms of the Creative Commons Attribution 3.0 Germany (CC BY 3.0 DE), which permits use, reproduction, and distribution in any medium, provided the original author(s) and source are given credit.

See https://creativecommons.org/licenses/by/3.0/de/legalcode. 


\section{Contents}

1 Introduction 1536

2 Methods and data: timing of urban and vital transitions 1539

3 Results 1544

The contribution of migration, reclassification, and natural
movement to urbanisation at the national level (1821-1891)

3.2 The contribution of migration and natural movement to urbanisation for different types of economic development (18561891) 1551

4 Discussion 1559

$\begin{array}{ll}\text { References } & 1562\end{array}$

$\begin{array}{ll}\text { Appendix } & 1565\end{array}$ 


\title{
A regional perspective on the economic determinants of urban transition in $19^{\text {th }}$-century France
}

\author{
Philippe Bocquier ${ }^{1}$
}

Sandra Brée ${ }^{2}$

\begin{abstract}
BACKGROUND

Past analyses lead to contradictory results as to whether migration, demographic transition, or economic development is the main driver of urban transition. Results depend heavily on the analytical strategy.
\end{abstract}

\section{OBJECTIVE}

This paper's aim is to identify different profiles of economic activity and their effect on urban transition over the $19^{\text {th }}$ century in France to test three hypotheses: economic development acts on urban transition through migration; political and economic shocks better explain variations in the migration component of urbanisation than its natural components; the diffusion of the urban growth model of large cities explains urban transition in peripheral areas.

\section{METHOD}

The paper uses census data from 80 French counties - excluding Paris, Corsica, and counties disputed by Germany and Italy - for 1856 to 1891. Each component of urbanisation at county level is regressed on employment structure, controlling for neighbouring urbanisation and for distance to Paris and nearest large city.

\section{RESULTS}

Results confirm conclusions for Sweden and Belgium demonstrating that migration drove 19th-century urban transition. The migration component of urban transition is far more sensitive to employment structure and to political and economic instability than the natural components. The diffusion effect is marginal.

\footnotetext{
${ }^{1}$ Centre de recherches en démographie, Université catholique de Louvain, Belgium. Email: philippe.bocquier@uclouvain.be.

${ }^{2}$ Centre National de la Recherche Scientifique, Laboratoire de Recherche Historique Rhône-Alpes, France. Email: sandra.bree@cnrs.fr.
} 
Bocquier \& Brée: Regional perspective on economic determinants of urban transition in $19^{\text {th }}$-century France

\section{CONCLUSIONS}

Results concur with the hypothesis that the redistribution of economic production through migration, and not the demographic transition, drove the urban transition.

\section{CONTRIBUTION}

The relationship between economic development and urban transition is assessed through the interaction of employment profile and period. Similar methodology could be used to analyse urban transition in contemporary low- and middle-income countries.

\section{Introduction}

Demographers and economists have recently revived the debate on the drivers of urban transition - i.e., the change from a mainly rural to a mainly urban society - that was initiated by Zelinsky (1971). Like Bairoch (1988), who observed that the positive interaction between urbanisation and economic development in industrialised countries did not apply to developing countries, Fox (2012) points out that the presence of innovation in agriculture, transportation, and health may stimulate urban growth without economic growth, as observed in sub-Saharan Africa. Fox concurs with Dyson (2011) - who himself followed de Vries $(1984,1990)$ - who states that population growth through declining mortality may be a stronger contributor to urban transition than economic growth. Other authors consider that besides the better survival prospects in urban areas, it is mainly changes in economic production that increases net migration to urban areas, through land pressure, productivity increase, institutional changes, and other factors (Bocquier and Costa 2015).

The debate is not closed, since results seem to strongly depend on the countries, data, and indicators selected. In the field of demographics, Bocquier and Costa (2015) show that taking migration and reclassification ${ }^{3}$ components into consideration may lead to different conclusions than using birth and death data only, as Dyson (2011) did for Sweden. Trends in both Sweden and Belgium suggest that vital transition, i.e., the interplay of fertility and mortality, plays a secondary, unstable, and negative role in urban transition, while migration explains most of it in the long term. These conclusions for European countries call into question de Vries's argument (1984) that spatially differentiated vital transition leads to urban transition, and reinstate Zelinsky's hypothesis (1971) that mobility transition, and therefore the redistribution of economic

${ }^{3}$ Reclassification may go both ways: rural (or urban) municipalities may be reclassified as urban (or rural) when their population reaches a threshold above (or below) which municipalities are considered urban (or rural), or when the state decides for administrative or political reasons that the municipality should be considered urban (or rural). 
production, drove the urban transition and not the demographic transition. Regarding the urban transition post-World War II, census data has shown that the contribution of natural growth to urban growth varied between $51 \%$ and $69 \%$ in 76 developing countries, depending on the period and the region (United Nations 2015). However, these figures do not reveal the extent to which natural and migration components of growth contribute to urban-rural growth difference, and consequently to the increase in the rate of urbanisation. Estimating the components of the contemporary urban transition remains a contentious issue, since the data to do so is unavailable or not readily accessible, even at country level.

In the economics field, several authors use econometric panel regression models to analyse the role of urban natural increase, GDP per capita growth, education, and other factors in contemporary urbanisation (Christiaensen, Gindelsky, and Jedwab 2013; Fox 2012; Henderson, Roberts, and Storeygard 2013). Baudin and Stelter (2016) use the generalised method of moments to build an urban and rural growth model that includes rural exodus as well as mortality and fertility components, using historical Danish data. They conclude that rural exodus was key to urban and economic transitions and that declining mortality played a positive yet marginal role in these transitions, which contradicts the conclusions on contemporary transitions made by the previously cited economists and Adams (2017) on long-term transition in England.

Our contention is that the larger the geographical scale, the more important and complex the hierarchical dependence between sub-spaces, be they states or lower administrative boundaries within states. By hierarchical dependence we mean that a space (a state at the international level or counties at the sub-national level) depends on another with greater economic and political power. It is important to consider interspace competition and centre-periphery hierarchy in any analysis of transition in a productive and reproductive (economic and demographic) system. In this regard, migration to urban areas within a sub-space or migration to other sub-spaces can be considered as a reallocation of human resources to the centres of economic power.

The relative importance of each component of the urban transition will depend on when, where, and how economic and institutional changes occurred, which makes each analysis very space- and time-specific and may prevent generalisation. The geographical level and the period in which these components are measured are important in order to account explicitly for local change in the relevant economic hierarchy. To control for hierarchical dependency it is important to explicitly model political and economic shocks in addition to structural political relations and economic dependence.

In the present paper we aim to address the above theoretical issues by looking at the case of France. We start by checking whether the results previously obtained for Sweden and Belgium (Bocquier and Costa 2015) are confirmed for France. We apply 
the same methodology to French provincial counties over the $19^{\text {th }}$ century $(1821-1891)$, when the urban transition started in France. However, our purpose is slightly different: not only do we aim to identify the migration and natural components of urban growth but we link these components to the economic profile of counties. France has an advantage over other large Western European countries such as Germany and the United Kingdom in that municipality (commune) and county boundaries were consistent over the $19^{\text {th }}$ century (with the exception of disputed counties; see next section) and thus consistent series of population counts, births, deaths, reclassification, and occupation can be extracted from remarkably well-maintained statistical books. France is a sufficiently large country to be able to identify different economic activity profiles and their effect on urbanisation, although in our case the analysis will be limited to 1856-1891 due to data constraints. Our first hypothesis is that economic activity is driving the urbanisation process through its migration component and not through natural components, thus testing Zelinsky's hypothesis against de Vries'. The coincident advantage of considering the second half of the century is that France went to war with the Prussian empire in 1870, which resulted in a major economic crisis in the 1870s. This political and economic shock represents a sensitivity test of the migration, natural, and reclassification components of urbanisation. By controlling for the interactions between each of these components and observation periods, we will explicitly model the effect of shocks on the urban transition. Our second hypothesis is that the 1870s shock explains much more of the variation in the migration component than the natural and reclassification components of urbanisation. This hypothesis tests the sensitivity of the urban transition to political and economic shocks through the variation in the migration component. Finally, our third hypothesis is that proximity to the highly urbanised Seine county (Paris) and to major cities (Lyon, Marseille, Bordeaux, Rouen, Nantes, etc.) impacts positively on urbanisation: the urban way of life would diffuse from the centre (Paris) to the periphery (possibly through major cities) and affect the components of urbanisation; e.g., by reducing mortality and fertility in the county's urban areas or by increasing long-term migration flows to major cities rather than to nearer regional centres. Indeed, the city is a place of innovation and diffusion of techniques and demographic behaviours. It promotes the monetisation of the economy, facilitates social mobility and the matching of supply and demand of skilled labour, and extends industrial and agricultural production outlets (Bairoch 1996).

Working on provincial French counties will help identify the above-mentioned hierarchical dependence by integrating distance to major urban centres into the model. Our methodological objective is to test on long-term French data a methodology that could be used for analysing hierarchical dependence in the post-World War II urban transition of large countries, or globally using countries as statistical units. 


\section{Methods and data: timing of urban and vital transitions}

The following is a summary of the methodology used in Bocquier and Costa (2015) for Belgium and Sweden, complemented by some details from the French data. The idea is to use basic aggregated data on population, births, and deaths by area of residence to deduce the migration component of population growth without direct measurement of migrations. Rates of increase in time interval $h$ in rural $r$ and urban $u$ areas are defined as:

$q_{h}^{u}=b_{h}^{u}-d_{h}^{u}+m_{h}^{u}+i_{h}^{u}$

$q_{h}^{r}=b_{h}^{r}-d_{h}^{r}+m_{h}^{r}+i_{h}^{r}$

where the rates $b_{h}^{r}, d_{h}^{r}, m_{h}^{r}, i_{h}^{r}$ are respectively the crude birth rate, crude death rate, net internal migration rate, and net international migration rate, all in period $h$. In addition to the natural and migration components, urban reclassification growth $\left(c_{h}^{u}\right.$, when, most of the time, a locality becomes urban just by crossing a relative or absolute population threshold or as decided by central authorities) and rural reclassification growth $\left(c_{h}^{r}\right.$, when, more rarely, a locality becomes rural) should be accounted for in equations (1a) and (1b) whenever data permits. Reclassification may itself occur as a result of cumulated growth over the years through migration, natural growth, or a combination of both.

For the proportion of the population living in urban areas to increase, the difference between urban and rural growth is more relevant than the urban growth. Although population growth in both urban and rural areas usually owes more to natural growth than to migration growth, the urban-rural growth difference may originate in either higher urban-rural natural growth difference or higher urban-rural migration growth difference. Therefore, we are interested in all the components, including reclassification, of the urban-rural difference in population growth:

$q_{h}^{u}-q_{h}^{r}=\left(b_{h}^{u}-b_{h}^{r}\right)-\left(d_{h}^{u}-d_{h}^{r}\right)+\left(m_{h}^{u}-m_{h}^{r}\right)+\left(i_{h}^{u}-i_{h}^{r}\right)+\left(c_{h}^{u}-c_{h}^{r}\right)$

To make the figures below easier to read, each difference in urban-rural rates in (2) is abbreviated:

$\Delta \mathrm{G}=\Delta \mathrm{CBR}-\Delta \mathrm{CDR}+\Delta \operatorname{intM}+\Delta \operatorname{extM}+\Delta \mathrm{R}$

where $\Delta \mathrm{G}$ stands for urban-rural growth difference, $\Delta \mathrm{CBR}$ for urban-rural difference in crude birth rate, $\triangle \mathrm{CDR}$ for urban-rural difference in crude death rate, $\triangle$ intM for urban- 
Bocquier \& Brée: Regional perspective on economic determinants of urban transition in $19^{\text {th }}$-century France

rural difference in internal net migration, $\Delta$ extM for urban-rural difference in international net migration, and $\Delta \mathrm{R}$ for urban-rural difference in net reclassification. It is enough to know the urban-rural growth difference $(\Delta G)$ and the urban-rural difference in natural growth $(\Delta \mathrm{N}=\Delta \mathrm{CBR}-\Delta \mathrm{CDR})$ to deduce the remaining components $(\Delta \operatorname{int} M+\Delta$ extM $+\Delta R)$. Data on reclassification $(\Delta R)$ is fairly easily collected using lists of localities by size. When data on births and deaths is also available for the reclassified localities, the migration $(\Delta \mathrm{RM})$ and natural $(\Delta \mathrm{RN})$ contributions to the reclassification component are computed such that:

$\Delta \operatorname{intM}+\Delta \operatorname{extM}=\Delta \mathrm{G}-(\Delta \mathrm{CBR}-\Delta \mathrm{CDR})-(\Delta \mathrm{RN}+\Delta \mathrm{RM})$

The total direct and indirect (i.e., through reclassification) contribution of migration to urban-rural growth difference is therefore:

$\Delta$ intM $+\Delta \operatorname{extM}+\Delta \mathrm{RM}=\Delta \mathrm{G}-(\Delta \mathrm{CBR}-\Delta \mathrm{CDR})-\Delta \mathrm{RN}$

$\Delta$ Mtotal $=\Delta \mathrm{G}-\Delta$ Ntotal

where:

total migration contribution $=\Delta \mathrm{Mtotal}=\Delta \mathrm{intM}+\Delta \mathrm{extM}+\Delta \mathrm{RM}$

total natural contribution $=\Delta$ Ntotal $=(\Delta \mathrm{CBR}-\Delta \mathrm{CDR})-\Delta \mathrm{RN}$

All growth rates and growth differences will be given per 1,000.

French statistical Mouvements de la population yearbooks that include birth and death counts by county were published regularly from the 1800 s, as well as censuses that were conducted every five years, with some exceptions (1826 and 1841 are not available and the 1871 census was postponed to 1872). Most of this historical data is available online through EHESS's Centre for Historical Research website (https://acrh.revues.org/2890). Births and deaths in urban areas for the years 1821$1824,1876,1887$, and 1889 are missing. Therefore, the corresponding period's total figures were extrapolated from figures for documented years. Certain other events and behaviours can bias birth and death counts. Indeed, according to Garden and Le Bras (1988), it is likely that 200,000 urban deaths due to the 1870-1871 Franco-Prussian war were unrecorded, half of which were outside the Seine county. Additionally, the practice that persisted in the $19^{\text {th }}$ century of fostering children - with urban middle-class and élite families sending their newborns to rural wet nurses for breastfeeding and care - is actually associated with higher but unrecorded infant mortality, a good example of a counterproductive strategy against urban health risks (Garden and Le Bras 1988; Rollet 1978, 1982). Underestimation of both war-related adult deaths and deaths of 
fostered infants means that urban mortality rates and the urban-rural mortality difference were underestimated.

Our definition of urban areas differs from that used in the official statistical yearbooks, which considered all municipalities of more than 2,000 inhabitants as urban. The threshold of 2,000 for municipalities is often considered too low as a definition of urban areas, as it is more sensitive to population growth leading to reclassification of municipalities from rural to urban. For the $20^{\text {th }}$ century a threshold of 10,000 is quite common, but in the $19^{\text {th }}$ century a threshold of 5,000 was more often used. This was also the threshold used in Belgian statistical books during the same period.

We collected data on urban municipalities that are chefs-lieux (administrative centres) and cities of more than 10,000 inhabitants and removed the chefs-lieux of fewer than 5,000 inhabitants. The limitation of our data is that it does not capture cities of 5,000 to 10,000 inhabitants that are not chefs-lieux, since they are not identified in the original yearbooks. We were able to count the number of deaths and births for all chefslieux that were reclassified (crossing the 5,000 threshold either way) and for all municipalities that were reclassified as cities by reaching the threshold of 10,000 . This enabled us to compute the contribution of migration and natural movement to reclassification. Given that employment data was consistent from the 1856 to the 1886 census, we had to limit our study of the impact of economic profile to the 1856-1891 period and to all départements except for the Seine (the county that includes the capital city, Paris), Corsica (because of its insularity), and those disputed by Germany and Italy over the $19^{\text {th }}$ century, i.e., the regions of Alsace and Lorraine and the counties of Savoie and Haute-Savoie. The Seine was excluded since it was already more than $80 \%$ urban at the beginning of the $19^{\text {th }}$ century (Brée 2015). For convenience, we will use the term 'provincial France' for the 80 selected counties in our analysis.

However, the influence of the Seine as a centre of political and economic power is taken into account in the regression analysis (see below) through a road-distance metric. We also computed road distances between each county's chef-lieu (or administrative centre) and the closest of the ten largest French cities other than Paris. If Paris was closer than any of these cities, then this variable takes on the same value as the variable capturing the distance to Paris. This redundancy occurs in ten counties, and in one period only for another six counties. The ten largest cities of over 100,000 inhabitants are, in alphabetic order, as follows (relevant years in brackets if the city was not among the top ten cities exceeding 100,000 for the entire 1851-1886 period): Bordeaux, Brest (1851, 1866), Le Havre (1871-1886), Lille, Lyon, Marseille, Nantes (1851-1881), Reims (1881-1886), Roubaix (1871, 1876, 1886), Rouen, Saint-Etienne (1856-1886), Strasbourg (1851-1866), Toulon (1851-1861), Toulouse. This was to control for the possible impact of metropolitanisation in the county's vicinity at the beginning of each inter-census period. For the same reason, we controlled for the urbanisation level in the 
neighbouring counties by computing the percentage that was urban in the total population of adjacent counties. Distance to closest large city and neighbouring urbanisation varies from one period to the next for each county depending on the development of the largest cities and on urbanisation in neighbouring counties. The three variables (distance to the capital city, distance to the closest large provincial city, neighbouring urbanisation) control for an external 'diffusion' effect of the urban growth model that might not be directly related to the 'endogenous' economic effect of the county's economic structure. Finally, we also controlled for the non-linear pattern in urban-rural growth difference in relation to the urban proportion (Bocquier 2005, 2015) by including the urban proportion and its squared term as covariates, both varying from one period to the next.

Two variables reflect push and pull factors that could play a role in urban transition independently of employment structure, urbanisation level, and distance to main cities. The push factor is the county's rural population density measure as the population of rural municipalities of fewer than 2,000 inhabitants (which includes most rural municipalities, i.e., excluding towns and cities) divided by the total number of hectares in the county. This rural density indicator is expressed in population per 1,000 hectares. This indicator does not perfectly capture land pressure since actual arable land area is not available, only the total area of the county. The pull factor is the availability of education, measured by the number of schools for all the county's municipalities. Since data on schools was not always available at the time of the census, the indicator was first computed for the available years and then interpolated to the census years, no more than two years apart from the recorded years. This indicator is expressed as the number of schools per 10 municipalities.

The main independent variable is the employment structure for males. Unfortunately, female employment during the $19^{\text {th }}$ century was often categorised as that of the male spouse, 'housewife,' or 'without occupation' (Motte and Pelissier 1992; Schweitzer 2002). Analysis of civil registers has shown that the more humble the husband's social category, the more likely it is that the woman's activity will be known (Motte and Pelissier 1992). The employment of women in industry is better known because they had a profession distinct from that of their husbands. However, the data was not consistently collected over the study period and across sectors.

Seven categories are available throughout the study period: agriculture, industry, commerce/transport (transport did not form a specific employment category before 1881), public sector (administration, army, police), clergy, and a residual category labelled 'others'. The latter is quite heterogeneous but includes mainly liberal professions (doctors, lawyers, etc.), but also annuitants, beggars, and those with no (declared or acceptable) activity. 
A Ward's linkage cluster analysis was performed to classify counties according to the percentage distribution of the seven categories of employment. However, the clergy employment category is non-discriminant in the cluster analysis, and so the four classes are essentially the result of the six other employment categories. It is noted that the cluster analysis was performed on county-period unit of analysis; that is, each unit was the combination of a period and a county. That way each county can change cluster from one period to the next, depending on change in its employment structure. Four classes were easily identified (see dendrogram in Figure A-1), ranked, and labelled (approximate proportions of employment are shown in parentheses: see Table A-1 for exact figures). The resulting four classes are ordered here from most to least agricultural, the most industrialised with higher-than-average tertiary employment. These four classes clearly represent a hierarchy of income and productivity, since industrial and tertiary activities were generating more income than agriculture in the $19^{\text {th }}$ century (Dormois 2005; Lévy-Leboyer and Bourguignon 1985; Marchand and Thélot 1997):

1. Large majority (3/4) agriculture: other categories are lower than average.

2. Majority agriculture (2/3), below-average industry (1/5): this is the largest category and closest to the average French provincial county over the study period except for 1881, when it was outnumbered by the third category.

3. Mostly agriculture (1/2), average industry (1/4), and higher-than-average commerce/transport and 'others'.

4. Much-lower-than-average agriculture (1/4), large industry (4/10), and higherthan-average commerce/transport and 'others'.

A naïve model of employment contribution to each growth component would use the original seven categories of employment share as parameters in the regression, as if each of these components could act independently of one another. This would assume that the contribution of a particular category of employment is the same whatever the structure of employment in the county. However, a ceteris paribus reasoning is not possible since any increase in the share of a category can only be made at the expense of another. Instead, the four classes from the cluster analysis readily account for this interdependence and offer a direct interpretation in terms of employment structure. In the regression analysis the four classes interact with period to account for possible evolution of the employment structure's effect on the components of urban-rural growth difference. This is to capture the impact of the post-1870-war crisis and recovery, which might depend on the employment structure. Graphs are thus constructed (Figure 9) to show in each of the four clusters the variations over time of 
the components of urbanisation, net of other effects (level of urbanisation and diffusion effects).

The seemingly unrelated regressions (SUR) model used for analysis belongs to the class of generalised structural equation models (GSEM). With this type of model, a set of equations is defined for different outcomes, but the error terms are assumed to be correlated, as they should be when outcomes for the same statistical units are actually related. The urban-rural growth differences in mortality, fertility, reclassification, and migration for the 80 provincial counties are regressed in four separate 'seemingly unrelated' equations on the employment cluster to which the county belongs, interacted with period, the urban proportion and squared term (to account for the potential nonlinear effect of urbanisation), the urban proportion in neighbouring counties, and the distance to Paris and closest large city, also interacted with period. Because the four components of urban-rural growth difference could be correlated to each other, a GSEM accounting for covariance between each pair of the four components is preferred over four 'completely unrelated' regression models, one for each component. A robust estimation method was tested to avoid the possible influence of outliers, but no difference with the ordinary estimation method was found, which is reassuring as far as the quality of the data is concerned.

In addition to the regression results, we computed the percentage contribution of each component of urban-rural growth difference net of other effects (also termed the mean 'marginal effects' of the main independent variable, computed at the mean value of control variables) in each cluster. This is a way to compare the regression results directly to the descriptive results, and thus to assess the role of control variables and outliers. If the results do not differ, the descriptive variations are then largely due to the combination of cluster and period effects and marginally due to control variables. If they do differ from the descriptive results, then the combined cluster-period effects obtained from the regression model will be interpreted as the underlying effect of the employment structure on each component of urban growth over time, all things being equal.

\section{Results}

This section starts with a descriptive analysis of the four components (births, deaths, reclassification, migration) of urban-rural growth difference in the 1821-1891 period. Then a regression analysis is performed on a more restricted period (1856-1891) for which we have data on employment structure, albeit for males only. 


\subsection{The contribution of migration, reclassification, and natural movement to urbanisation at the national level (1821-1891)}

The population of France was 31.39 million in 1821 and reached about 38.34 million in 1891. As in most Western European countries, the urban transition really started in the $19^{\text {th }}$ century. The percentage urban in provincial France (as defined by us; see above) rose from $10.6 \%$ (3.04 million urban) in 1821 to $16.8 \%$ in 1856 (5.42 million urban), and $22.0 \%$ in 1886 ( 7.43 million urban). This is 10 to 15 percentage points less than the official definition that includes municipalities of 2,000 to 5,000 inhabitants and the Seine county, which increased from $83 \%$ to $94 \%$ urban in the same period using our definition against $94 \%$ to $99 \%$ with the 2,000 inhabitants threshold (Brée 2015). Using our definition of urban, the trend is similar with and without Seine county (Figure 1).

Figure 1: Proportion of urban population in France and provincial France (1821-1886)

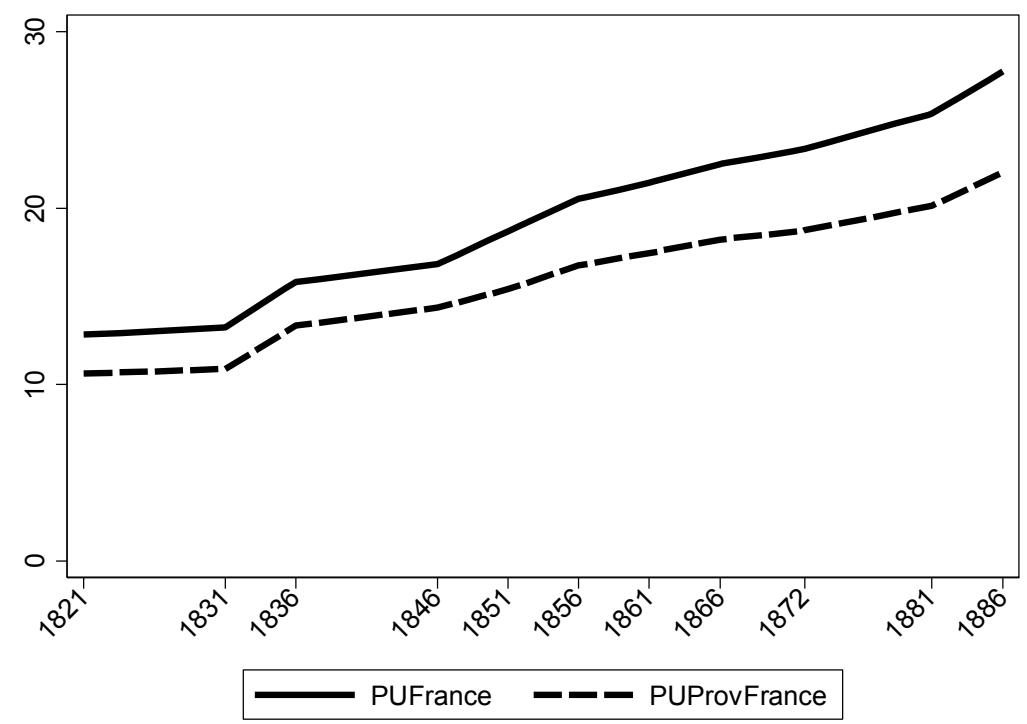

Note: Definition of urban: chefs-lieux of 5,000 inhabitants or more and other urban municipalities of 10,000 inhabitants or more.

Crude birth and death rates per 1,000 (Figure 2) show a downward trend over the 1821-1891 period, interrupted by a peak of mortality in the war period (1866-1872). 
Crude death rates are constantly higher in urban areas, thus confirming the 'urban penalty', although a sharp decrease in the urban crude death rate was observed in the 1836-1846 period. Crude birth rates were higher in urban areas prior to 1836 but did not differ much in urban and rural areas thereafter, being slightly lower in urban areas from 1836 to 1872 . The downward trend in fertility for provincial France exemplifies here the singularity of French fertility in the European landscape. Even without considering the highly urbanised, low-fertility Seine county (Brée 2017), fertility had already started to decline in both urban and rural areas before the $19^{\text {th }}$ century. Using data from Henry's survey, Bardet (1998) dates the first fertility decline at around 17901800, whereas Knodel and Van de Walle (1979) suggest 1827 as the first year of decline, using Coale and Treadway's definition (irreversible fertility decline of $10 \%$ or more compared to the pre-transitional value). The cities' precedence in fertility decline (Sharlin 1986) has been observed several times, e.g., in Rouen and in Paris (Bardet 1983; Brée 2017; Bardet 1998).

\section{Figure 2: Crude birth and death rates (per 1,000) in urban and rural provincial France (1821-1891)}

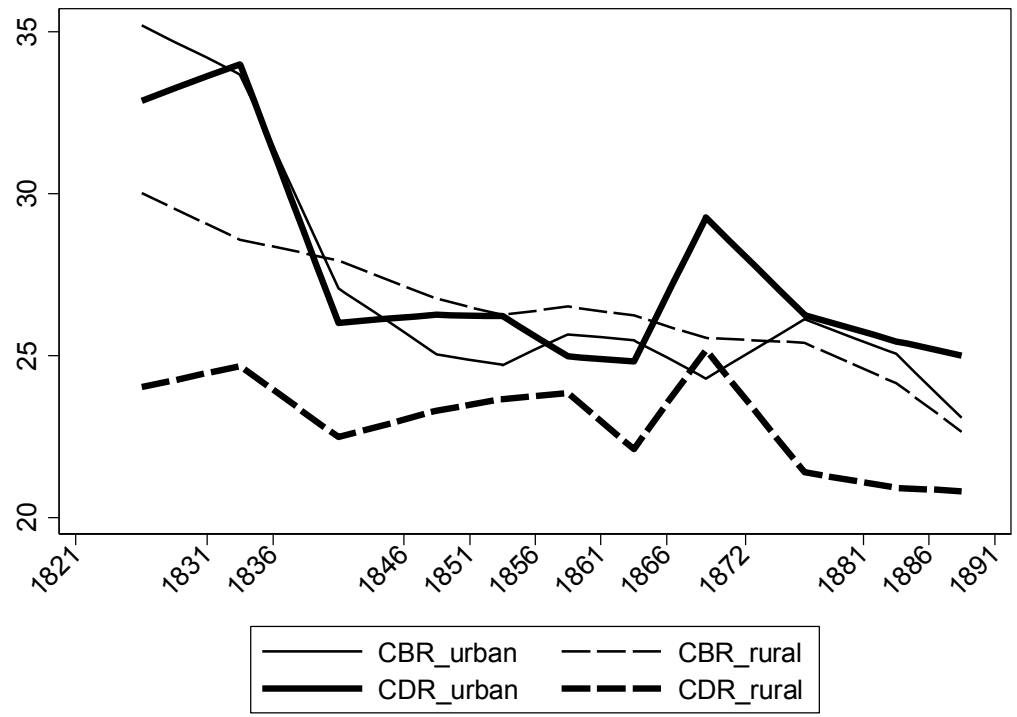

Overall, the natural growth rate $(=\mathrm{CBR}-\mathrm{CDR})$ is always positive in rural areas, even during the war period, while in urban areas it hovers around zero or is even markedly negative during the war period. These trends in provincial France thus 
confirm the phenomenon of the 'urban demographic sink' (a prolonged negative natural growth) observed elsewhere in $19^{\text {th }}$-century Europe, despite the downward mortality and fertility trends.

Despite the urban demographic sink attributed to natural growth, the total growth rate per 1,000 as shown in Figure 3 is always positive over the 1821-1891 period in urban areas, with many ups and downs of around +12.3 per 1,000 on average, while the total growth rate in rural areas $(+0.3$ per 1,000 over the whole period) shows a downward trend from positive in $1821-1851(+3.6$ per 1,000$)$ to generally negative or nil thereafter $(-1.6$ per 1,000$)$. This contrasts with the urban demographic sink previously identified in Figure 2. The difference can only be due to migration and to a lesser extent reclassification, as shown in the following analysis of the components of urban-rural growth differences.

Figure 3: Total growth rates (per 1,000) in urban and rural provincial France (1821-1891)

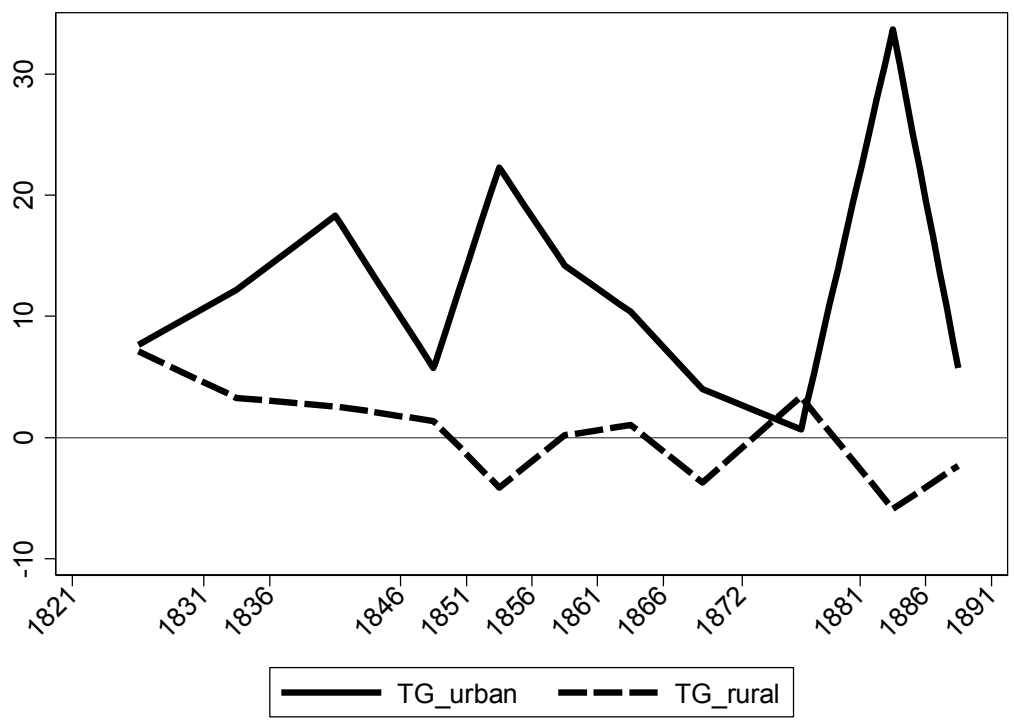

Figure 4 depicts the difference in vital transition between urban and rural areas ( $\triangle \mathrm{CBR}, \Delta \mathrm{CDR}$, and the resulting $\Delta \mathrm{N}$ ) as well as the trends in urban-rural migration plus reclassification growth difference $(\Delta \mathrm{RMG}=\Delta \mathrm{int} \mathrm{M}+\Delta \mathrm{extM}+\Delta \mathrm{R})$. In the 1821-1836 period, urban areas have higher crude birth and death rates than rural areas, leading to a typical case of 'urban penalty' (excess urban mortality) not quite compensated for by 
higher fertility. After 1836, urban areas experience lower crude birth rates than rural areas, but also higher crude death rates. Natural growth difference is thus detrimental to urban areas $(\Delta \mathrm{N}$ hovers around -4.2 per 1,000$)$, at times because of mortality and at others because of fertility. The urban demographic sink is persistent and almost constant. This is different from both Sweden (excess urban mortality with not much urban-rural difference in births) and Belgium (births compensating for excess mortality in urban areas) (see Figures A-2 and A-3 in the Appendix).

Figure 4: Urban-rural difference (per 1,000) in mortality (dCDR), fertility (dCBR), migration cum reclassification (dRMG), and total growth (dG) in provincial France (1821-1891)

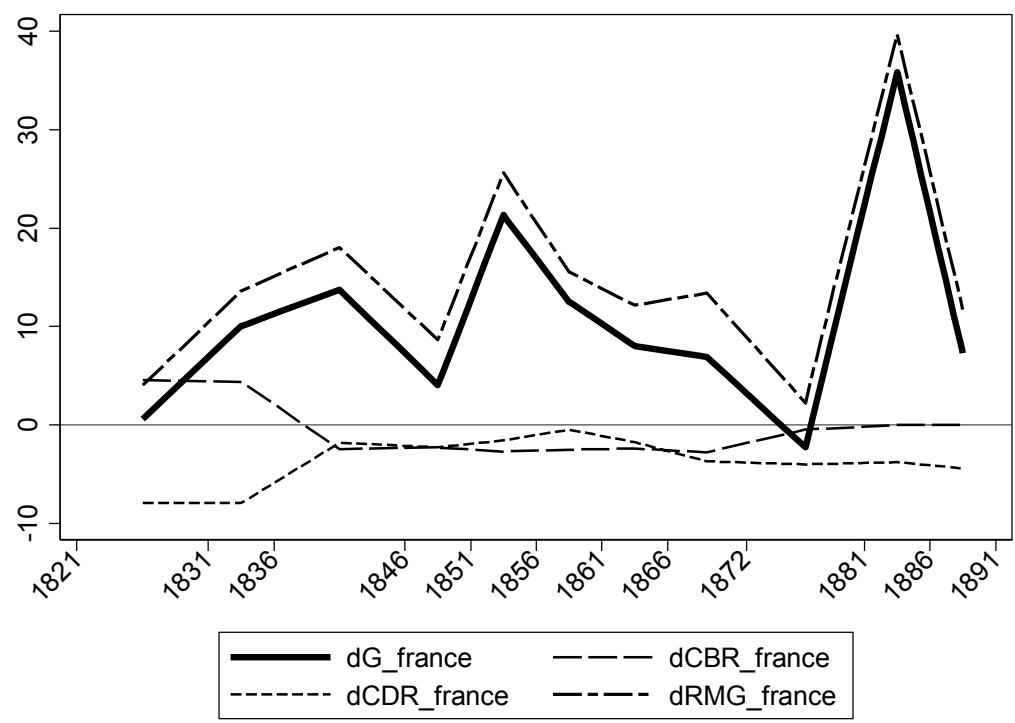

The most important trend depicted in Figure 4 is that migration together with reclassification highly contributed (correlation: $99.6 \%$ ) to the level of and variation in urban-rural total growth difference $(\Delta \mathrm{G})$, contrary to the natural component (correlation: 18.5\%). Urban growth was mostly positive over the study period, with the noticeable exception of the post-war crisis period (1872-1881). This was the period following the turmoil of the Franco-Prussian war (1870-1871), various civil insurrections in several cities (the most famous in Paris in 1871), the fall of the Second Empire (Napoleon III), and the establishment of the Third Republic. Migration and reclassification bounced back in the $1881-1886$ period. This period is characterised by 
the return of relative political stability and by economic recovery under the presidency of Jules Grévy, despite historians dubbing the 30-year period from the 1870 war to the end of the $19^{\text {th }}$ century "the Long Depression" (Lhomme 1970).

Figure 5 repeats the total growth difference $(\Delta G)$ and natural growth difference $(\Delta \mathrm{NG})$ from Figure 4 but separates the migration component from the reclassification component. Total urban-rural growth difference per 1,000 is highly correlated with both reclassification $(61.3 \%)$ and migration $(91.9 \%)$, as compared to natural growth (only $18.5 \%$ correlation). Figure 5 shows that over the 1821-1891 period, reclassification made a positive contribution $(+3.1$ per 1,000 on average) while the migration contribution is nearly four times higher $(+11.9$ per 1,000 over the same period) despite being negative in 1872-1881. The 1881-1886 period shows a peak in urban-rural growth difference with a high contribution of migration and reclassification.

Figure 5: Urban-rural difference (per 1,000) in direct natural movement (dNG), direct migration (dMG), reclassification (dR), and total growth (dG) in provincial France (1821-1891)

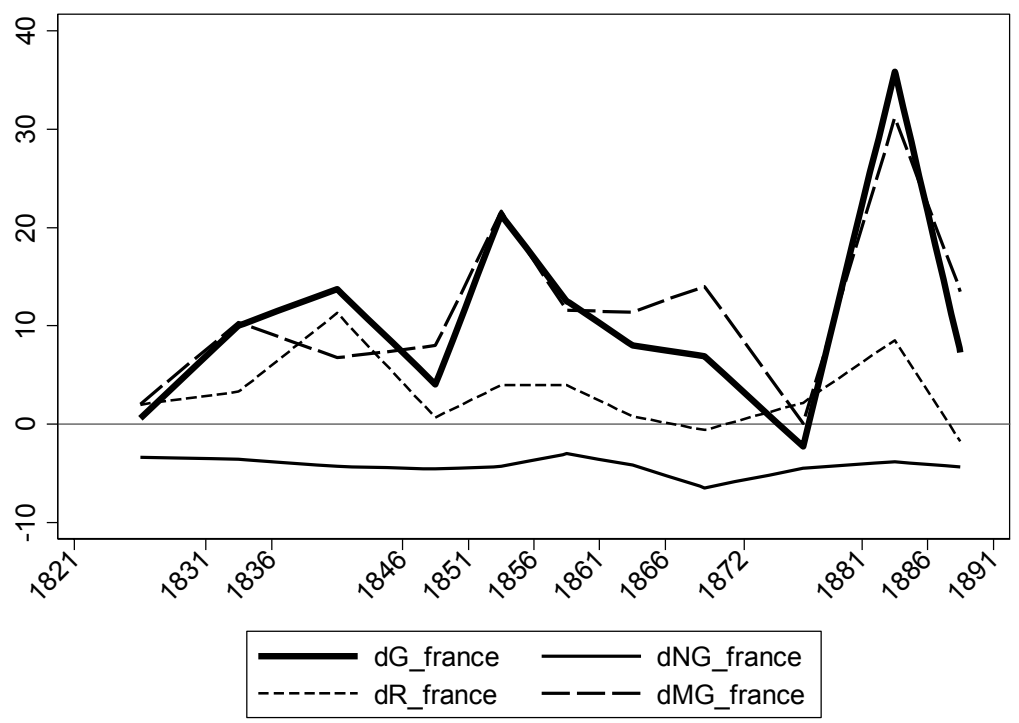

As explained in the methods section, we were able to further separate the natural and migration components of reclassification. Actually, $99.75 \%$ of reclassification $(+3.1$ per 1,000 on average over the study period) is explained by migration and the rest 
by natural movement. Therefore, the indirect contribution (through reclassification) of natural movement adds very little to the direct negative contribution $(-4.2$ per 1000) of natural movement to overall urban-rural growth difference.

Drawing the indirect and direct contributions as two separate trends for natural and migration growth (Figure 6) shows quite clearly that in provincial France the overall level and variation of the urban-rural growth difference is determined by migration. The correlation of natural movement with urban-rural growth difference over the whole study period is very weak (12.8\%) compared to the migration component $(98.5 \%)$. The data shows that migration was the main and positive contributor to the French urban transition in the $19^{\text {th }}$ century, while natural movement contributed negatively but marginally to hampering it.

Figure 6: Urban-rural difference (per 1,000) in total natural movement (dNtot), total migration (dMtot), and total growth (dG) in provincial France (1821-1891)

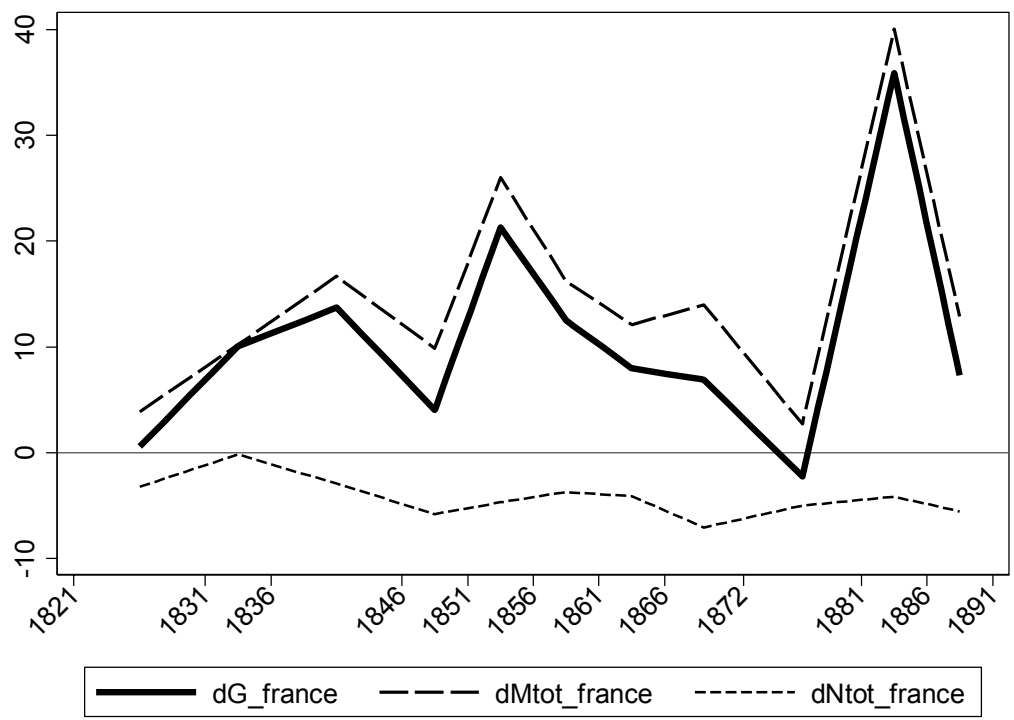

Trends in France as depicted in Figure 5 are interesting to compare with those of Belgium (Figure A-2) and Sweden (Figure A-3). The characteristics of the urban demographic sink are not universal. In Sweden this sink, observed prior to 1850, was essentially due to excess mortality in urban areas, and was gradually eliminated in 1850-1880. In Belgium there is no evidence of the urban demographic sink prior to the 
urban transition: a slight urban excess mortality was compensated for by excess fertility in urban areas up to 1900. If there was a sink it was rather weak and occurred after urban transition started and was mainly due to a birth deficit in urban areas in the first half of the $20^{\text {th }}$ century. In provincial France there was a prolonged urban demographic sink due to higher urban death rates and often-lower urban birth rates.

In Belgium over the $19^{\text {th }}$ century, reclassification contributed more than twice as much to the urban-rural growth difference than the migration component, and about half of this reclassification was due to migration. In Sweden the contribution of reclassification is positive but low before World War I. In France, reclassification contributed much less than the migration component and was largely due to migration, thus adding to its direct effect.

Replicating the analysis on historical demographic series for France has confirmed the conclusion drawn from Belgium and Sweden. At the national level of the three countries, the direct and indirect (through reclassification) role of migration was prominent in the urban transition that began in the $19^{\text {th }}$ century. In particular, variations in urban-rural growth difference are sensitive to the migration component. Our analyses confirm that effects of mortality and fertility on urban transition are not constant through history and are generally either weak or negative, while migration has a higher, positive, and sustained effect. Therefore, urbanisation is not an inevitable outcome of the vital transition, as hypothesised by de Vries (1990) and Dyson (2011). Although data from other countries would be necessary to be able to generalise this to Europe, our results for France, Belgium, and Sweden seem to confirm the two hypotheses made in a previous paper (Bocquier and Costa 2015): "mobility transition is a necessary and underlying condition for urban transition" and "vital transition is an unnecessary contribution to urban transition". Using very different analytical techniques on Danish data for the period 1840-1940, Baudin and Stelter (2016) conclude that the rural exodus

played a substantial role in Denmark's economic and demographic transitions, while the role of mortality reduction was weak.

\subsection{The contribution of migration and natural movement to urbanisation for different types of economic development (1856-1891)}

We start this section with a descriptive analysis of the four classes from the cluster analysis, hereafter 'clusters' (Figure 7). We do not comment on the reclassification component, as it follows the general migration trend - thus basically accentuating the migration component's effect on urbanisation. It is important to note here that the net migration component is the residual of the demographic balancing equation: Migration data is not available and the migration component can only be estimated by its 
difference with the natural and reclassification components. In particular, we cannot separate migration within the county from that to other counties or to foreign countries.

In the majority agricultural cluster the migration component always has a positive effect on urbanisation, with a peak in the recovery period (1881-1886) and a drop in the post-recovery period (1886-1991). Mortality does not differ much between urban and rural areas, while the fertility component contributes negatively to urbanisation in this cluster. However, in the recovery and post-recovery periods the gap between the mortality and fertility components shrinks, essentially because the contribution of fertility becomes less negative. In the average agricultural cluster the migration component is always positive, except in the post-war crisis period (1872-1881) when it is nil, while the recovery peak is visible but much less pronounced than in the majority agricultural cluster. Both the mortality and fertility components contribute negatively over the study period. In the half-agricultural cluster the migration component more or less follows the same trend as in the previous average agricultural cluster although the effect is less pronounced (the recovery peak is only visible if we take reclassification into account). The trend for the mortality and fertility components is almost the opposite to that for the majority agricultural cluster: starting at an almost equal level at the beginning of the study period they diverge with time, with the mortality component becoming more and more negative, while the fertility component is nil at the end of the post-recovery period. In the industrial and diversified cluster the migration component's trend is very pronounced, with the only case of negative contribution occurring in the crisis period (1872-1881) and with a high peak in the recovery period (1881-1886) accentuated by reclassification. As for the natural components, they first diverge up to the crisis period, with mortality having a negative effect and fertility a positive one, and then converge, with fertility having a nil effect and mortality still having a slightly negative effect in the post-recovery period.

To sum up this descriptive analysis based on Figure 7, the migration and the reclassification components are much more sensitive to the political and economic circumstances than the natural components, with a higher dampening effect of the postwar crisis on the more industrialised and diversified clusters, but with a high recovery peak at both ends of the employment spectrum; i.e., for both the majority agricultural and industrial and diversified clusters. As for the urban demographic sink (the negative contribution of natural growth to urbanisation), it obeys very different rules depending on the employment structure: the more industrialised and diversified the employment structure is, the more the mortality component contributes to the sink, and the more fertility goes from being a negative contribution to a positive one. 
Figure 7: Contribution of births, deaths, reclassification, and migration components to the urban-rural growth difference (per 1,000) in the four employment clusters (1856-1891)

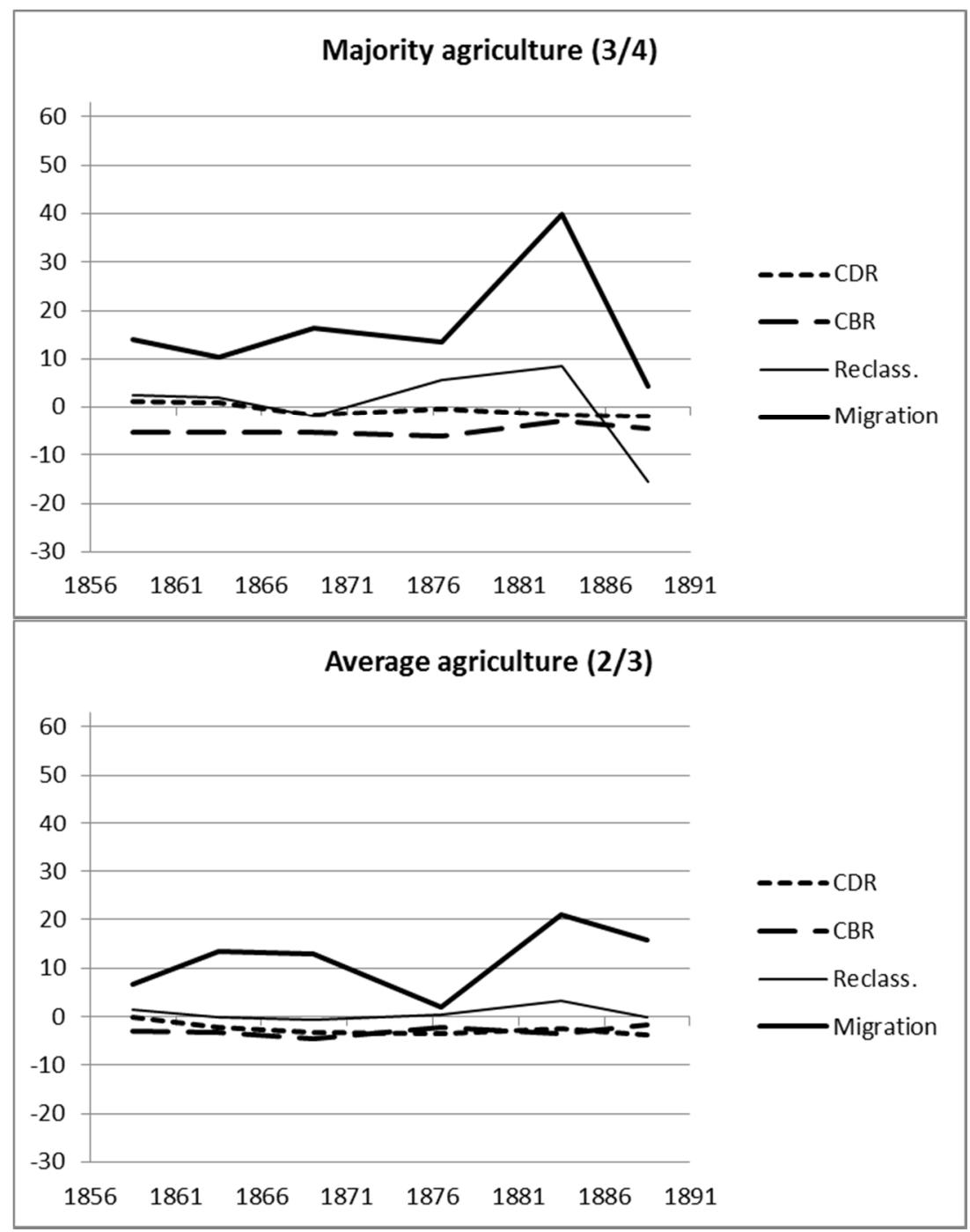


Figure 7: (Continued)

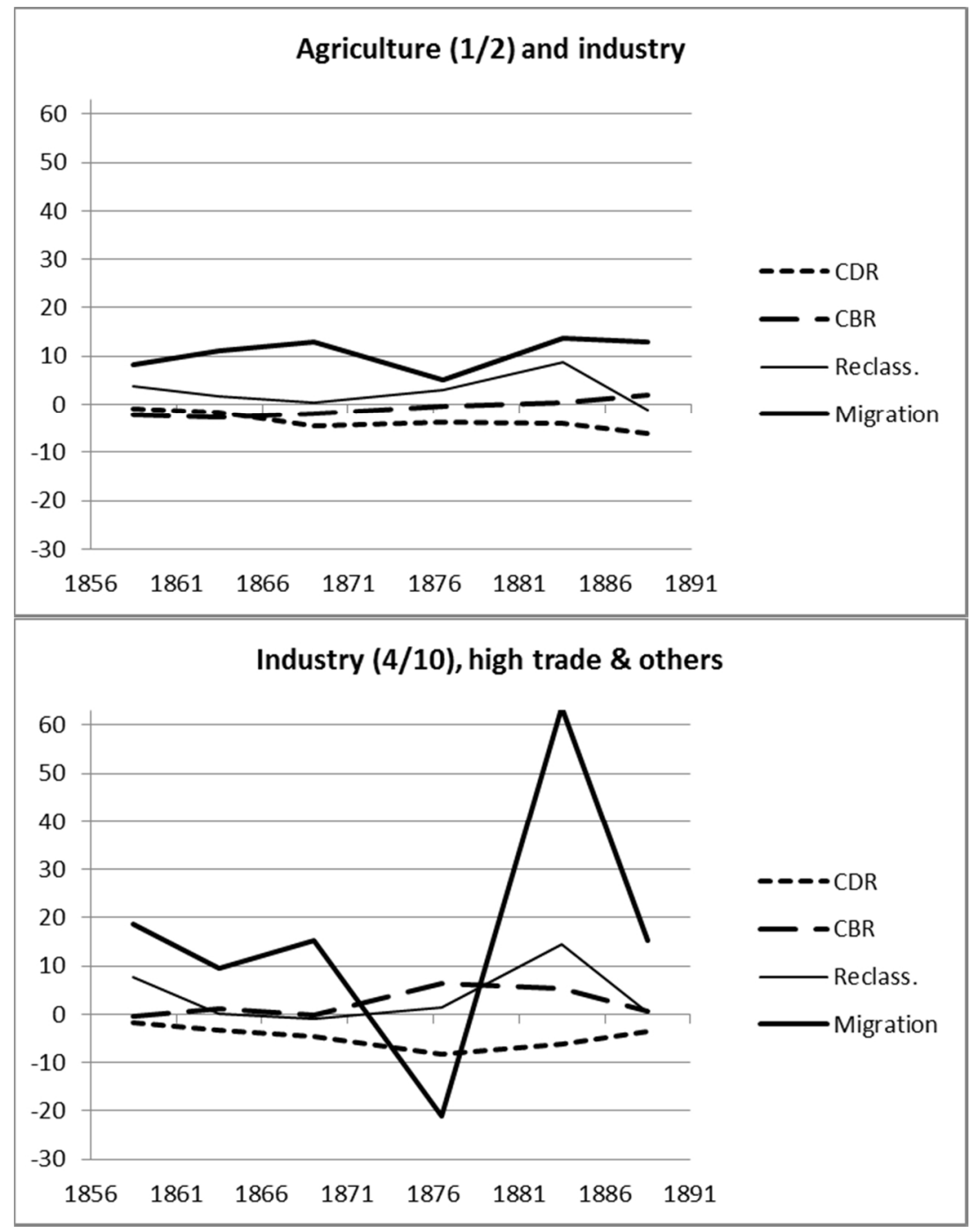

The remainder of this section presents the results of the regression analyses for each of the mortality, fertility, reclassification, and migration components described above. The regression variables are employment clusters, urbanisation indicators, 
distance to main cities, rural density, and the availability of education (see methods section).

Figure 8: Net component contributions (per 1,000) to urbanisation by employment profile (1856-1891)

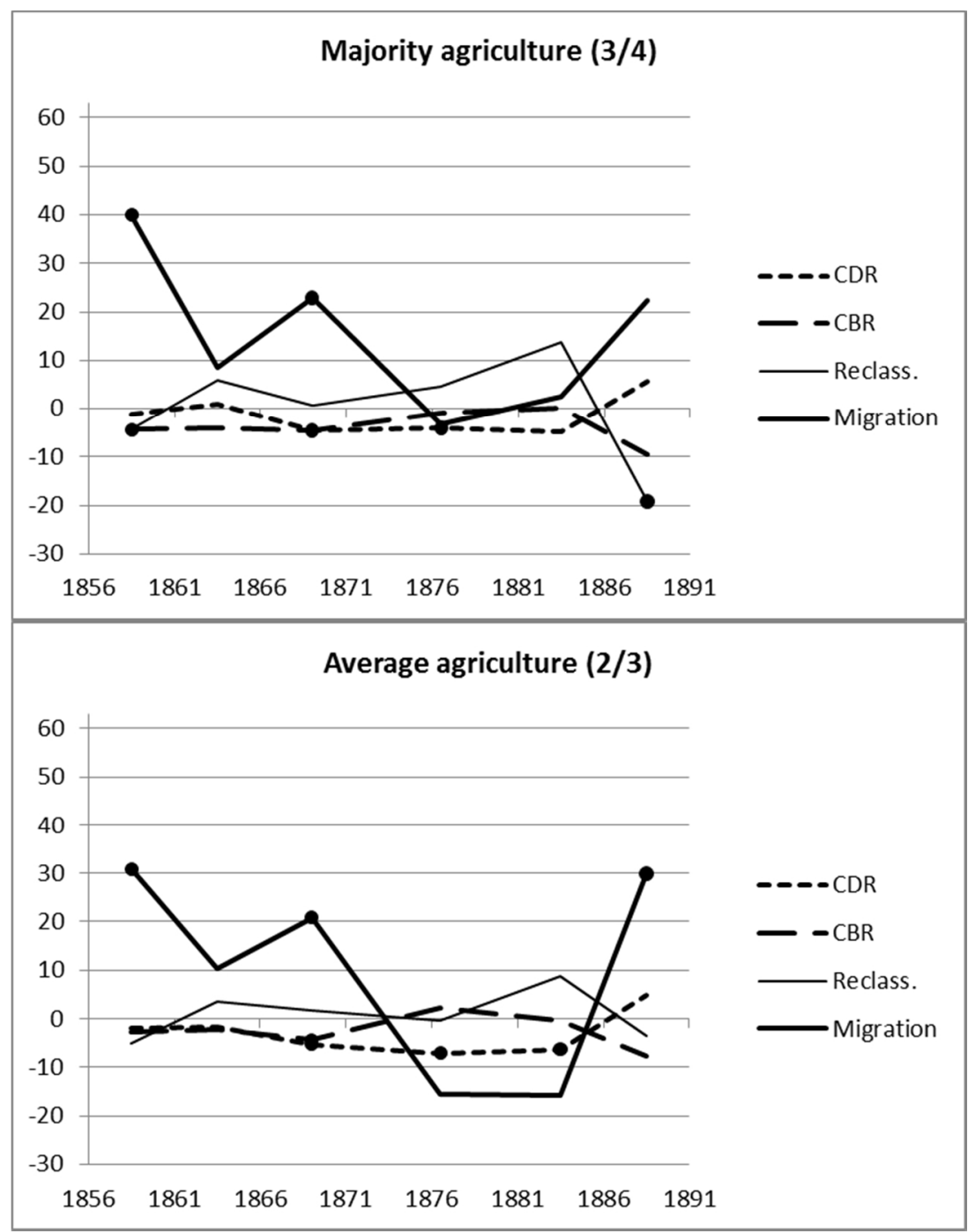


Figure 8: (Continued)

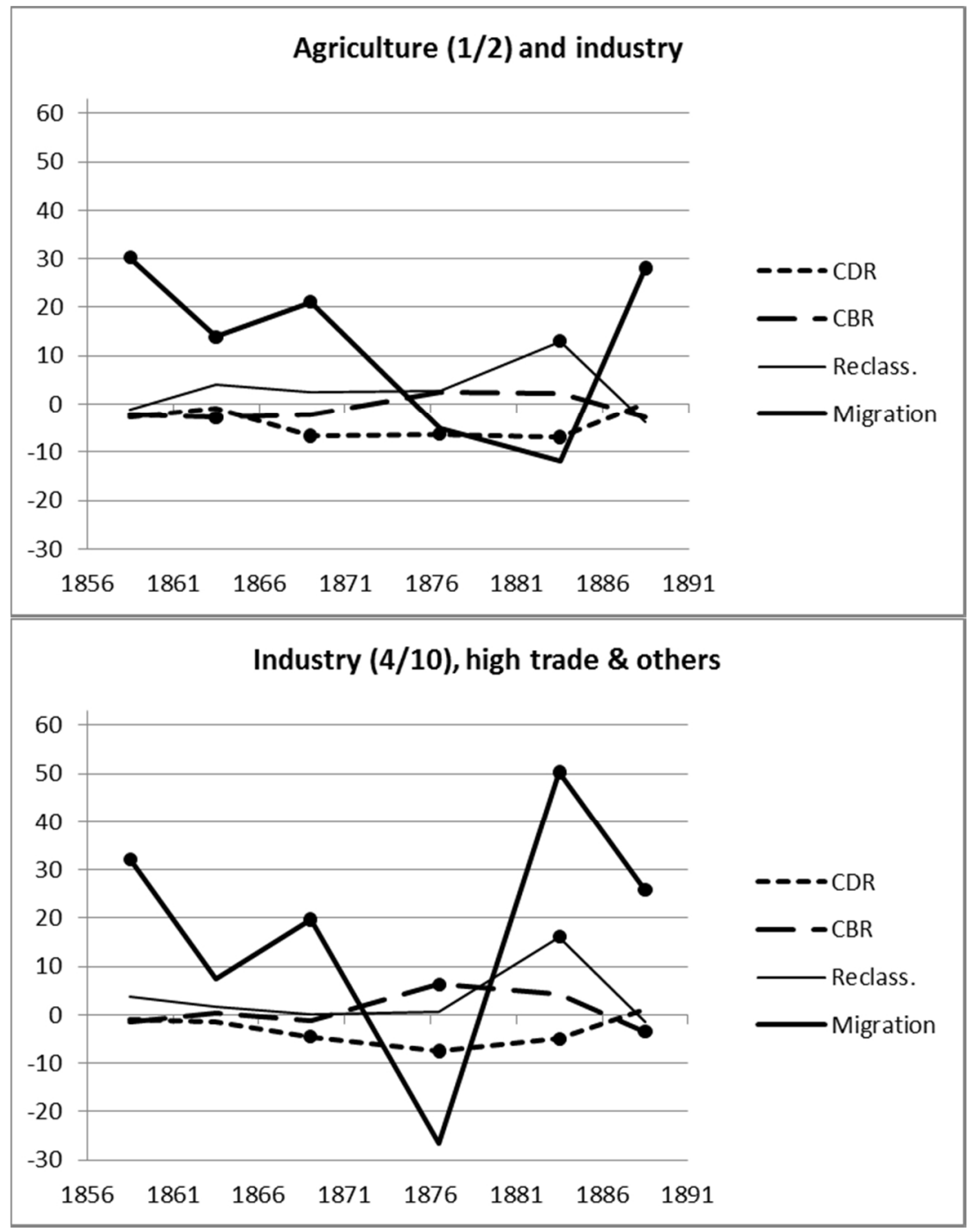

Note: Estimates marked with a black dot are significantly different from $0 ; p$-value $<0.05$

The effects of the structure of employment are more easily interpretable through the margins (Figure 8; the regression results are available in Table A-2); i.e., the 
estimated components of urbanisation in each employment profile cluster and for each inter-census period, all other factors (urbanisation level, urbanisation of neighbouring counties, distance to Paris and large cities, rural density, availability of education) being equal. For convenience, we refer to the regression model results as the 'net component of urbanisation,' as opposed to the 'gross component of urbanisation,' which refers to the descriptive results (Figure 7) to which the margins are directly comparable.

The first remarkable regression result is that the net migration component of urbanisation is accentuated as compared to the descriptive results and shows a similar U-shape pattern across employment profiles. It declined steadily from 1856 and became negative in the crisis and recovery period, except in the industrial and diversified cluster. The general pattern for the recovery and post-recovery periods differs in the net and gross patterns. The gross migration component for all provincial France shows a peak in the recovery period which is only visible in the net migration component for the industrial and diversified cluster. For the other clusters the peak is actually observed for the net reclassification component, which we recall is mainly due to migration. Moreover, the level of the net migration component in the post-recovery period is comparable in all clusters (between $2 \%$ and $3 \%$ ).

The second remarkable feature is that the net mortality and fertility components also differ from their gross counterparts. The pattern is also much more similar across clusters in the net than in the gross estimations. Generally, the urban penalty due to higher mortality in urban areas (as compared to rural areas) is not really apparent before 1866. Even during the post-war period of crisis and recovery (1872-1886), higher mortality is never compensated for by higher fertility in urban areas. The situation is reversed in the very last, post-recovery period (1886-1891): mortality benefits urban areas (there is no more urban penalty) while fertility is again detrimental to urban areas as in the pre-war period, particularly in the more agricultural county clusters.

What other covariates in the regression model could reveal what is hidden in the gross components of urbanisation? The level of urbanisation is significant $(\mathrm{p}<0.01)$ for the fertility component only, while the effect of urbanisation in neighbouring counties is never significant, whatever the component. Greater distance to closest large city reduced the fertility component of urbanisation during the crisis (1872-1881) and recovery (1881-1886) periods by about $-0.18 \%$ for each $100 \mathrm{~km}$, but hardly significantly. Similarly, greater distance to closest large city increased the mortality component (i.e., reduced the urban penalty) during both the crisis $(-0.20 \%$ for each 100 $\mathrm{km} ; \mathrm{p}<0.0005)$ and recovery periods $(-0.22 \%$ for each $100 \mathrm{~km} ; \mathrm{p}<0.033)$. Distance to closest large city increases the migration contribution significantly $(\mathrm{p}<0.006)$ in the crisis period (1872-1881) by $+1.36 \%$ for each $100 \mathrm{~km}$. Distance to Paris has no effect on the fertility component and a mildly significant but weak effect on the mortality component of urbanisation, increasing it by $+0.06 \%(\mathrm{p}<0.009)$ in the war period (1866- 
Bocquier \& Brée: Regional perspective on economic determinants of urban transition in $19^{\text {th }}$-century France

$1872)$ and by $+0.04 \%(\mathrm{p}<0.036)$ in the following crisis period for each $100 \mathrm{~km}$. Distance to Paris increases the migration contribution to urbanisation in the 1861-1866 pre-war period (by $+0.25 \%$ for each $100 \mathrm{~km}, \mathrm{p}<0.014$ ) and in the $1881-1886$ recovery period (by $+0.63 \%$ for each $100 \mathrm{~km}, \mathrm{p}<0.036$ ).

To sum up, the effect of greater distance to a large city is to reduce the natural components of urbanisation mainly in the crisis and recovery periods. This means that the pattern (an increased gap between the mortality and fertility components) observed in the crisis and recovery periods for the net natural components (Figure 7) is essentially associated with the counties hosting large cities or with the counties nearby. The distinctly negative mortality contribution and the slightly positive fertility contribution were therefore limited historically to the crisis and recovery periods and spatially to central counties (i.e., with large cities within reach), at a time when these counties attracted fewer migrants. In other words, the post-war negative net migration in these counties revealed the underlying negative effect of mortality (urban penalty) and positive effect of fertility.

We note that the effect of distance to Paris for the natural components of urbanisation is limited in time to before the employment structure variable is introduced into the model (negative effect on the fertility component after the war, positive effect on the mortality component during the war and crisis periods) and disappears after it is introduced (compare the results in Tables A-2 and A-3 in the Appendix). Also, the effect of distance to Paris on the migration component before the war is reduced after introducing the employment cluster variable. These cancelled or reduced effects mean that employment better explains variations in the migration, mortality, and fertility components of urbanisation than proximity to Paris. In fact, the effect of distance to large cities on the migration component remains almost unaffected by the introduction of the employment cluster variable.

In conclusion, in terms of distance to main cities, the effect of distance to Paris on natural components is mediated by the employment structure, while the migration component of urbanisation is strongly driven by the overall national political and economic situation and to a lesser extent by difference in employment structure. Although detailed migration data by origin and destination is lacking, our analysis leads us to assume that the post-war period led to a redistribution of long-distance migration previously oriented toward urbanised central counties to cities in less-urbanised (i.e., peripheral) counties. In the meantime, the population of central counties experienced an urban penalty not quite compensated for by a fertility advantage, possibly due to a higher proportion of reproductive-age population.

Availability of education (pull factor) is positively but non-significantly associated with the fertility contribution $(+0.017 \%$ per additional school for 10 municipalities; $\mathrm{p}<0.054)$ and is negatively associated with the mortality contribution $(-0.024 \%$ per 
additional school for 10 municipalities; $\mathrm{p}<0.008$ ), while it has no significant effect on the migration contribution. Similarly, rural density (push factor) is positively associated with the fertility contribution $(+0.043 \%$ per additional rural inhabitant for 1,000 hectares; $\mathrm{p}<0.027)$ and is negatively associated with the mortality contribution $(-0.063 \%$ per additional rural inhabitant for 1,000 hectares; $p<0.0005)$, while it has no significant effect on the migration contribution. The effects of both availability of education and rural density do not differ before and after introducing the employment structure variable. It is worth noting that the negative association with mortality compensates for the positive association with fertility for both variables. Therefore, these factors have a net negative effect on the natural component of urbanisation while having no effect on the migration component - which is rather unexpected, since these factors were thought to push, or pull, population toward urban areas. Also, the effect of availability of education is counterintuitive, since its negative effect on the mortality component contributes to the urban penalty.

\section{Discussion}

Our analysis of the role of employment in the components of urbanisation at the county level in France has pointed to the crucial role played not so much by a particular component or sector of the economy but by the structure of a county's economy and by the national political and economic context. The regression analysis using four clusters of counties according to their employment structures as determinants, controlling for urbanisation level and diffusion factors (urbanisation of neighbouring counties, distance to large cities and Paris) and for push and pull factors (rural density and availability of education), clearly shows the underlying urban penalty and period effects in the central counties (within reach of the largest cities) that were not apparent using descriptive statistics only. Results show how a shock (the 1870-1871 Franco-Prussian war and post-war crisis) affected urbanisation negatively through its migration component and probably redistributed migration temporarily towards smaller cities in peripheral counties. These results concur with those of Lerch and Stegemann (2017), who show how the business cycle and the political context affected internal and international migration to Zurich in the $19^{\text {th }}$ and $20^{\text {th }}$ centuries, and how Zurich's population dynamics depended on the relative attractiveness of its economy. Their analyses and ours confirm that interspace competition and centre-periphery hierarchy cannot be ignored when analysing urban transition. Therefore, controlling for geographical scale and historical period is essential to the methodology of transition analysis, particularly to identify where political and economic shocks strike hard. 
Bocquier \& Brée: Regional perspective on economic determinants of urban transition in $19^{\text {th }}$-century France

As regards checking our initial hypotheses, results largely confirm that economic activity drives the urbanisation process through its migration component and not through its natural components. In the net component analysis the urban penalty (excess urban mortality) - confirmed found only between 1866 and 1886 (the war, crisis, and recovery periods) - is partially compensated for by higher urban fertility, and only marginally explains the slowdown in urbanisation, essentially in the most urbanised counties. Indeed, these natural component effects are not discernible in the gross component analysis. On the contrary, the net component analysis reveals that the 18701871 shock and its aftermath explain variations in the migration component much more than those in the natural components of urbanisation. The reclassification component, which is driven mainly by migration, somewhat compensated for the direct migration component deficit during the recovery period. As in Belgium and Sweden, the overall direct and indirect contribution of migration to urbanisation by far exceeds the natural contribution before, and to an even greater degree after, controlling for the economic structure and other control variables. The results for the three countries contradict de Vries' hypothesis that demographic transition drove the urban transition and concur with Zelinsky's hypothesis that the redistribution of economic production, through mobility transition, drove the urban transition.

Conversely, our hypothesis regarding the geographical diffusion of the urban growth model from the centre (Paris) to the periphery (possibly through major cities) is not confirmed. The natural components of urbanisation are affected by distance to these cities only indirectly through the employment structure, which further confirms our previous hypothesis on the role of the economy in the urbanisation process. The migration component is only temporarily affected by distance, mainly to large cities during the crisis period and marginally to Paris in the recovery period, with migration presumably redistributed to smaller urban centres during these periods. The hierarchical dependence (interspace competition and centre-periphery hierarchy) does not act directly on urban transition by way of proximity to the centres of economic and political power (e.g., Paris and large cities) but essentially through the employment structure and the redistribution of migration.

However imperfectly measured the rural density and availability of education variables may be, their effects suggest that these push and pull factors do not impact migration but rather fertility and mortality behaviours. Contrary to expectations, their effects are detrimental to urbanisation and are independent of the employment structure. This further confirms that the migration component of urbanisation is driven first and foremost by employment opportunities (the employment structure has a much stronger effect) and not by land pressure or opportunities to invest in children's education. This is congruent with the conclusions of Heywood (1981) on the role of the peasantry in $19^{\text {th }}$-century France: if industrialisation did not make much progress at the time it is not 
because of a lack of ability on the part of the peasantry to seize urban opportunities but rather because of the lack of these opportunities. We add that the war and post-war crisis greatly contributed to this lack of urban opportunity.

The residual method used in this paper to evaluate the migration component has its limits. To better characterise the role of the migration component of urban transition, more detailed data on migration flows by origin and destination would be necessary. In particular, checking our assumption of redistribution of migration flows to the detriment of large cities during periods of crisis would require intra- versus inter-county migration data. Similarly, international net migration cannot be distinguished from internal net migration, as was done by Lerch and Stegemann (2017) for Zurich. Also, the effects of migration on sex and age structure cannot be assessed with the type of data used in this paper, although these effects may explain variations in the mortality and fertility components. For example, the change from male-dominated circular migration to permanent family migration over the $19^{\text {th }}$ century (Châtelain 1967; Kesztenbaum 2006) certainly had an impact on urban transition that the data at hand could not evaluate.

Beyond the analysis of historical French data, the modelling approach adopted in this paper could be applied to other contexts. The urban transition could be analysed in the same way at the international level, given data availability. The $19^{\text {th }}$-century French example teaches us to be cautious regarding direct measures of the employment sector's effect and determinants that do not interact with the period effect. Following this paper's methodology, a typology of employment structure (rather than each employment sector independently), controlling for urbanisation level and various measures of distance (to the nearest large metropolis, to the former colonial capital city, etc.) and other push and pull factors could be used to explain the four components of urban transition and their variations over time, taking low- and middle-income countries (LMIC) as geographical units of analysis in relation to the contemporary international centres of economic and political power. This would be helpful to examine the so-called urbanisation without economic growth observed in low-income countries (Africa and some Asian countries). Direct measurement of internal and international migration by origin and destination would obviously be a great improvement on the method, which would be helpful for checking how economic cycles (crisis and recovery) are, or are not, favouring urbanisation in LMICs through a redistribution of migration from international to internal destinations, depending on their economic profile and dependency. 
Bocquier \& Brée: Regional perspective on economic determinants of urban transition in $19^{\text {th }}$-century France

\section{References}

Adams, J.J. (2017). Urbanization, long-run growth, and the demographic transition. Gainsville: University of Florida, Department of Economics (Unpublished working paper).

Bairoch, P. (1988). Cities and economic development: From the dawn of history to the present. Chicago: University of Chicago Press.

Bairoch, P. (1996). Cinq millénaires de croissance urbaine. In: Sachs, I. (ed.). Quelles villes, pour quel développement. Paris: Puf: 17-60.

Bardet, J.-P. (1983). Rouen aux XVIIe et XVIIIe siècles. Paris: SEDES.

Bardet, J.-P. (1998). La France en déclin. In: Bardet, J.-P. and Dupâquier, J. (eds.). Histoire des populations de l'Europe: II. La révolution démographique, 17501914. Paris: Fayard: 287-325.

Baudin, T. and Stelter, R. (2016). Rural exodus and fertility at the time of industrialization. Louvain-la-Neuve: Université catholique de Louvain, Institut de Recherches Économiques et Sociales (Discussion paper 2016-20). https://sites.uclouvain.be/econ/DP/IRES/2016020.pdf.

Bocquier, P. (2005). World urbanization prospects: An alternative to the UN model of projection compatible with urban transition theory. Demographic Research 12(9): 197-236. doi:10.4054/DemRes.2005.12.9.

Bocquier, P. (2015). The future of urban projections: Suggested improvements on the UN method. Spatial Demography 2(2): 1-14. doi:10.1007/s40980-015-0005-1.

Bocquier, P. and Costa, R. (2015). Which transition comes first? Urban and demographic transitions in Belgium and Sweden. Demographic Research 33(48): 1297-1332. doi:10.4054/DemRes.2015.33.48.

Brée, S. (2015). La population de la région parisienne au XIX ${ }^{\mathrm{e}}$ siècle. Louvain-laNeuve: Université catholique de Louvain, Centre de recherche en démographie (Working paper 6). https://cdn.uclouvain.be/public/Exports\%20reddot/demo/ documents/Bree2sur1.pdf.

Brée, S. (2017). Paris l'inféconde: La limitation des naissances en région parisienne au XIX $X^{e}$ siècle. Paris: Ined Éditions.

Châtelain, A. (1967). Les migrations temporaires françaises au XIX ${ }^{\mathrm{e}}$ siècle: Problèmes, méthodes, documentation. Annales de Démographie Historique 1967: 9-28. 
Christiaensen, L., Gindelsky, M., and Jedwab, R. (2013). Rural push, urban pull or... urban push? New historical evidence from 40 developing countries. Silver Spring: Editorialexpress.com. https://editorialexpress.com/cgi-bin/conference/ download.cgi?db_name $=$ NEUDC2013\&paper_id $=56$.

de Vries, J. (1984). European urbanization, 1500-1800. London: Methuen.

de Vries, J. (1990). Problems in the measurement, description, and analysis of historical urbanization. In: van der Woude, A., Yayami, A., and de Vries, J. (eds.). Urbanization in history. Oxford: Clarendon Press: 43-60.

Dormois, J.-P. (2005). Le visible et les invisibles: La productivité des services en France et en Angleterre au cours de l'industrialisation. Revue d'Histoire Moderne et Contemporaine 52(4): 152-181. doi:10.3917/rhmc.524.0152.

Dyson, T. (2011). The role of the demographic transition in the process of urbanization. Population and Development Review 37(1): 34-54. doi:10.1111/j.1728-4457. 2011.00377.x.

Fox, S. (2012). Urbanization as a global historical process: Theory and evidence from sub-Saharan Africa. Population and Development Review 38(2): 285-310. doi:10.1111/j.1728-4457.2012.00493.x.

Garden, M. and Le Bras, H. (1988). La dynamique régionale. In: Dupâquier, J. (ed.). Histoire de la population française: III. De 1789 à 1914. Paris: Puf: 138-162.

Henderson, J.V., Roberts, M., and Storeygard, A. (2013). Is urbanization in subSaharan Africa different? Washington, D.C.: World Bank (Policy research working paper 6481).

Henry, L. (1967). Manuel de démographie historique. Paris: INED.

Heywood, C. (1981). The role of the peasantry in French industrialization, 1815-1880. The Economic History Review 34(3): 359-376.

Kesztenbaum, L. (2006). Une histoire d'espace et de patrimoine: Familles et migration dans la France de la Troisième République, 1870-1940 [PhD thesis]. Paris: L'Institut d'Études Politiques.

Knodel, J. and Van de Walle, E. (1979). Lessons from the past: Policy implications of historical fertility studies. Population and Development Review 5(2): 217-245. doi: $10.2307 / 1971824$. 
Bocquier \& Brée: Regional perspective on economic determinants of urban transition in $19^{\text {th }}$-century France

Lerch, M. and Stegemann, L. (2017). City growth in international perspective: The case of industrializing Zurich 1760-1949. Paper presented at the Population Association of America Annual Meeting, Chicago, April 26-29, 2017.

Lévy-Leboyer, M. and Bourguignon, F. (1985). L'économie française au XIXe siècle: Analyse macro-économique. Paris: Éditions Économica.

Lhomme, J. (1970). La crise agricole à la fin du XIX siècle en France: Essai d'interprétation économique et sociale. Revue Économique 21(4): 521-553.

Marchand, O. and Thélot, C. (1997). Le travail en France, 1800-2000. Paris: Nathan.

Motte, C. and Pelissier, J.-P. (1992). La binette, l'aiguille et le plumeau: Les mondes du travail féminin. In: Dupâquier, J. and Kessler, D. (eds.). La société française au XIX $X^{e}$ siècle. Paris: Fayard: 237-342.

Rollet, C. (1978). Allaitement, mise en nourrice et mortalité infantile en France à la fin du XIX siècle. Population (French edition) 33(6): 1189-1203.

Rollet, C. (1982). Nourrices et nourrissons dans le département de la Seine et en France de 1880 à 1940. Population (French edition) 37(3): 573-604.

Schweitzer, S. (2002). Les femmes ont toujours travaillé: Une histoire du travail des femmes aux XIX et $X X^{e}$ siècles. Paris: Odile Jacob.

Sharlin, A. (1986). Urban-rural differences in fertility in Europe during the demographic transition. In: Coale, A.J. and Watkins, S.C. (eds.). The decline of fertility in Europe: The revised proceedings of a conference on the Princeton European Fertility Project. Princeton: Princeton University Press: 234-260.

Statistiska Centralbyrån (1969). Historisk statistik för Sverige: Del 1: Befolkning, $2^{\text {nd }}$ edition, 1720-1967. Stockholm: Statistiska Centralbyrån. https://www.scb.se/ Grupp/Hitta_statistik/Historisk_statistik/_Dokument/Historisk-statistik-forSverige-Del-1.pdf.

United Nations (2015). World urbanization prospects: The 2014 revision. New York: United Nations, Department of Economic and Social Affairs, Population Division. https://esa.un.org/unpd/wup/publications/files/wup2014-report.pdf.

Zelinsky, W. (1971). The hypothesis of the mobility transition. The Geographical Review 61(2): 219-249. doi:10.2307/213996. 


\section{Appendix}

Figure A-1: Dendrogram justifying the clustering in four groups

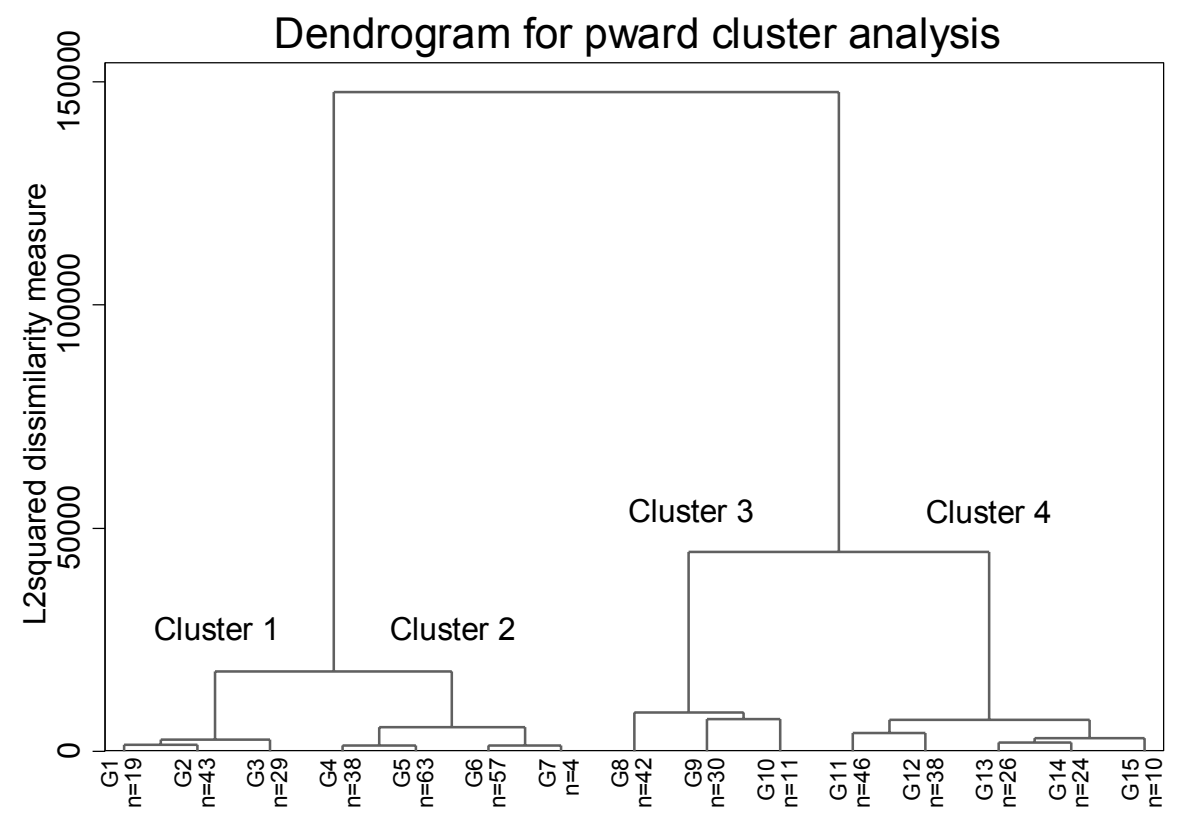

Table A-1: Percentage distribution of male employment sectors in the four clusters $(\mathrm{N}=\mathbf{4 8 0}$ periods, 80 counties $)$

\begin{tabular}{|c|c|c|c|c|c|c|c|}
\hline Cluster & $\begin{array}{l}\% \\
\text { agriculture }\end{array}$ & $\begin{array}{l}\% \\
\text { industry }\end{array}$ & $\begin{array}{l}\% \\
\text { commerce/transport }\end{array}$ & $\begin{array}{l}\% \\
\text { public sector }\end{array}$ & $\begin{array}{l}\% \\
\text { clergy }\end{array}$ & $\begin{array}{l}\% \\
\text { other }\end{array}$ & $\begin{array}{l}\text { Total } \\
\text { ( } N=\text { periods) }\end{array}$ \\
\hline 1. Majority agriculture & 73.8 & 13.6 & 3.4 & 1.9 & 0.6 & 6.8 & $\begin{array}{l}100.0 \\
(91)\end{array}$ \\
\hline 2. Average agriculture & 63.2 & 19.2 & 5.1 & 2.5 & 0.6 & 9.5 & $\begin{array}{l}100.0 \\
(162)\end{array}$ \\
\hline 3. Half agriculture & 51.9 & 24.7 & 7.1 & 3.1 & 0.6 & 12.6 & $\begin{array}{l}100.0 \\
(144)\end{array}$ \\
\hline 4. High industry & 36.4 & 38.2 & 8.6 & 2.9 & 0.6 & 13.3 & $\begin{array}{l}100.0 \\
(83)\end{array}$ \\
\hline Provincial France & 57.2 & 23.0 & 6.0 & 2.6 & 0.6 & 10.6 & $\begin{array}{l}100.0 \\
(480)\end{array}$ \\
\hline
\end{tabular}


Bocquier \& Brée: Regional perspective on economic determinants of urban transition in $19^{\text {th }}$-century France

\section{Table A-2: Generalized structural equation model with period-cluster interactions $(\mathrm{N}=480$ periods, 80 counties)}

\begin{tabular}{|c|c|c|c|c|c|c|}
\hline & Coef. & Std. Err. & $z$ & $\mathrm{P}>|\mathrm{z}|$ & $\begin{array}{l}\text { [95\% Conf. Interval] } \\
\text { Lower bound }\end{array}$ & Upper bound \\
\hline \multicolumn{7}{|l|}{$\Delta$ Crude birth rate } \\
\hline Cluster 1 1856-1861 & -.1654252 & .1255682 & -1.32 & 0.188 & -.4115344 & .0806841 \\
\hline Cluster 2 1856-1861 & [REF] & & & & & \\
\hline Cluster 3 1856-1861 & .0329945 & .0943973 & 0.35 & 0.727 & -.1520209 & .2180098 \\
\hline Cluster 4 1856-1861 & .1280603 & .1184967 & 1.08 & 0.280 & -.104189 & .3603096 \\
\hline Cluster 1 1861-1866 & -.1240144 & .2649766 & -0.47 & 0.640 & -.643359 & .3953302 \\
\hline Cluster 2 1861-1866 & .0384582 & .2303661 & 0.17 & 0.867 & -.4130511 & .4899675 \\
\hline Cluster 3 1861-1866 & -.01368 & .2174963 & -0.06 & 0.950 & -.4399648 & .4126048 \\
\hline Cluster 4 1861-1866 & .2960165 & .2065524 & 1.43 & 0.152 & -.1088188 & .7008518 \\
\hline Cluster 1 1866-1872 & -.1856375 & .2705722 & -0.69 & 0.493 & -.7159494 & .3446744 \\
\hline Cluster 2 1866-1872 & -.170505 & .2515587 & -0.68 & 0.498 & -.663551 & .322541 \\
\hline Cluster 3 1866-1872 & .0533046 & .2236453 & 0.24 & 0.812 & -.3850322 & .4916414 \\
\hline Cluster 4 1866-1872 & .1384245 & .2158926 & 0.64 & 0.521 & -.2847173 & .5615662 \\
\hline Cluster 1 1872-1881 & .1678369 & .3219953 & 0.52 & 0.602 & -.4632622 & .798936 \\
\hline Cluster 2 1872-1881 & .483464 & .2781561 & 1.74 & 0.082 & -.0617119 & 1.02864 \\
\hline Cluster 3 1872-1881 & .5257495 & .2561125 & 2.05 & 0.040 & .0237783 & 1.027721 \\
\hline Cluster 4 1872-1881 & .8993131 & .3613527 & 2.49 & 0.013 & .1910749 & 1.607551 \\
\hline Cluster 1 1881-1886 & .2862554 & .386674 & 0.74 & 0.459 & -.4716117 & 1.044122 \\
\hline Cluster 2 1881-1886 & .2285488 & .294768 & 0.78 & 0.438 & -.3491858 & .8062834 \\
\hline Cluster 3 1881-1886 & .496352 & .2641366 & 1.88 & 0.060 & -.0213463 & 1.01405 \\
\hline Cluster 4 1881-1886 & .6883648 & .3044544 & 2.26 & 0.024 & .0916451 & 1.285085 \\
\hline Cluster 1 1886-1891 & -.6885634 & .6139487 & -1.12 & 0.262 & -1.891881 & .5147539 \\
\hline Cluster 2 1886-1891 & -.50412 & .6189526 & -0.81 & 0.415 & -1.717245 & .7090048 \\
\hline Cluster 3 1886-1891 & -.0048082 & .3040705 & -0.02 & 0.987 & -.6007755 & .591159 \\
\hline Cluster 4 1886-1891 & -.0797988 & .2713408 & -0.29 & 0.769 & -.611617 & .4520195 \\
\hline Percent Urban & .0247967 & .0095162 & 2.61 & 0.009 & .0061453 & .0434481 \\
\hline Percent Urban squared & -.0004101 & .0001511 & -2.71 & 0.007 & -.0007063 & -.000114 \\
\hline$\%$ Urb adjac counties & .0037916 & .0044376 & 0.85 & 0.393 & -.0049059 & .0124892 \\
\hline \multicolumn{7}{|l|}{ distance Paris } \\
\hline 1856-1861 & -.0047338 & .0235859 & -0.20 & 0.841 & -.0509614 & .0414937 \\
\hline $1861-1866$ & -.0036038 & .0219502 & -0.16 & 0.870 & -.0466253 & .0394178 \\
\hline 1866-1872 & .0038029 & .0224414 & 0.17 & 0.865 & -.0401815 & .0477872 \\
\hline 1872-1881 & -.0399536 & .0268423 & -1.49 & 0.137 & -.0925636 & .0126563 \\
\hline 1881-1886 & -.0186202 & .0307296 & -0.61 & 0.545 & -.0788491 & .0416087 \\
\hline 1886-1891 & .0042508 & .0358918 & 0.12 & 0.906 & -.0660958 & .0745974 \\
\hline \multicolumn{7}{|l|}{ distance big city } \\
\hline $1856-1861$ & .0111527 & .068575 & 0.16 & 0.871 & -.1232518 & .1455571 \\
\hline 1861-1866 & -.0369207 & .0665469 & -0.55 & 0.579 & -.1673503 & .0935089 \\
\hline 1866-1872 & -.0270994 & .0769634 & -0.35 & 0.725 & -.177945 & .1237462 \\
\hline 1872-1881 & -.1812427 & .0919291 & -1.97 & 0.049 & -.3614205 & -.001065 \\
\hline 1881-1886 & -.1764769 & .1038328 & -1.70 & 0.089 & -.3799854 & .0270316 \\
\hline 1886-1891 & .2147553 & .2119198 & 1.01 & 0.311 & -.2005999 & .6301104 \\
\hline Schools / 10 municip. & .0170286 & .0088342 & 1.93 & 0.054 & -.0002861 & .0343433 \\
\hline Rural pop / 1000 ha & .0434283 & .0196405 & 2.21 & 0.027 & .0049335 & .081923 \\
\hline constant & -1.13111 & .2424035 & -4.67 & 0.000 & -1.606212 & -.6560082 \\
\hline
\end{tabular}


Table A-2: (Continued)

\begin{tabular}{|c|c|c|c|c|c|c|}
\hline & Coef. & Std. Err. & $z$ & $\mathrm{P}>|\mathrm{z}|$ & $\begin{array}{l}\text { [95\% Conf. Interval] } \\
\text { Lower bound }\end{array}$ & Upper bound \\
\hline \multicolumn{7}{|l|}{$\Delta$ Crude death rate } \\
\hline Cluster 1 1856-1861 & .0777638 & .13486 & 0.58 & 0.564 & -.1865568 & .3420845 \\
\hline Cluster 2 1856-1861 & {$[R E F]$} & & & & & \\
\hline Cluster 3 1856-1861 & -.066307 & .1081227 & -0.61 & 0.540 & -.2782236 & .1456097 \\
\hline Cluster 4 1856-1861 & .0982287 & .1394441 & 0.70 & 0.481 & -.1750768 & .3715342 \\
\hline Cluster 1 1861-1866 & .2993125 & .2709317 & 1.10 & 0.269 & -.2317038 & .8303288 \\
\hline Cluster 2 1861-1866 & .0247931 & .2455418 & 0.10 & 0.920 & -.45646 & .5060462 \\
\hline Cluster 3 1861-1866 & .0977549 & .221865 & 0.44 & 0.659 & -.3370926 & .5326023 \\
\hline Cluster 4 1861-1866 & .0494554 & .2321257 & 0.21 & 0.831 & -.4055025 & .5044134 \\
\hline Cluster 1 1866-1872 & -.2540974 & .3157666 & -0.80 & 0.421 & -.8729886 & .3647938 \\
\hline Cluster 2 1866-1872 & -.3295984 & .2597944 & -1.27 & 0.205 & -.838786 & .1795892 \\
\hline Cluster 3 1866-1872 & -.4638664 & .253732 & -1.83 & 0.068 & -.961172 & .0334391 \\
\hline Cluster 4 1866-1872 & -.252214 & .2272658 & -1.11 & 0.267 & -.6976467 & .1932188 \\
\hline Cluster 1 1872-1881 & -.1970892 & .2749521 & -0.72 & 0.473 & -.7359854 & .341807 \\
\hline Cluster 2 1872-1881 & -.5074536 & .2356805 & -2.15 & 0.031 & -.9693788 & -.0455283 \\
\hline Cluster 3 1872-1881 & -.4342873 & .2137216 & -2.03 & 0.042 & -.853174 & -.0154006 \\
\hline Cluster 4 1872-1881 & -.543145 & .2476118 & -2.19 & 0.028 & -1.028455 & -.0578348 \\
\hline Cluster 1 1881-1886 & -.2726892 & .3965021 & -0.69 & 0.492 & -1.049819 & .5044406 \\
\hline Cluster 2 1881-1886 & -.4297319 & .3216814 & -1.34 & 0.182 & -1.060216 & .200752 \\
\hline Cluster 3 1881-1886 & -.4883713 & .2863986 & -1.71 & 0.088 & -1.049702 & .0729596 \\
\hline Cluster 4 1881-1886 & -.2975623 & .2548448 & -1.17 & 0.243 & -.7970489 & .2019243 \\
\hline Cluster 1 1886-1891 & .7653373 & .6553446 & 1.17 & 0.243 & -.5191145 & 2.049789 \\
\hline Cluster 2 1886-1891 & .6708012 & .6595832 & 1.02 & 0.309 & -.6219581 & 1.96356 \\
\hline Cluster 3 1886-1891 & .2153687 & .3141517 & 0.69 & 0.493 & -.4003573 & .8310947 \\
\hline Cluster 4 1886-1891 & .3055672 & .2967438 & 1.03 & 0.303 & -.27604 & .8871744 \\
\hline Percent Urban & -.0077857 & .0098293 & -0.79 & 0.428 & -.0270507 & .0114793 \\
\hline Percent Urban squared & .0002324 & .0001477 & 1.57 & 0.116 & -.000057 & .0005218 \\
\hline$\%$ Urb adjac counties & .0049407 & .0050883 & 0.97 & 0.332 & -.0050322 & .0149135 \\
\hline \multicolumn{7}{|l|}{ distance Paris } \\
\hline $1856-1861$ & .047596 & .0239411 & 1.99 & 0.047 & .0006723 & .0945198 \\
\hline $1861-1866$ & .0216887 & .0224829 & 0.96 & 0.335 & -.0223769 & .0657543 \\
\hline $1866-1872$ & .0639474 & .0243348 & 2.63 & 0.009 & .0162521 & .1116428 \\
\hline $1872-1881$ & .0440995 & .0209751 & 2.10 & 0.036 & .0029891 & .08521 \\
\hline $1881-1886$ & .0388692 & .0304551 & 1.28 & 0.202 & -.0208218 & .0985601 \\
\hline 1886-1891 & .0142486 & .0366882 & 0.39 & 0.698 & -.0576589 & .0861561 \\
\hline \multicolumn{7}{|l|}{ distance big city } \\
\hline 1856-1861 & .0596796 & .0709658 & 0.84 & 0.400 & -.0794108 & .19877 \\
\hline $1861-1866$ & -.0153026 & .0634783 & -0.24 & 0.810 & -.1397178 & .1091126 \\
\hline $1866-1872$ & .0412033 & .0715863 & 0.58 & 0.565 & -.0991033 & .1815099 \\
\hline $1872-1881$ & .1956568 & .0511699 & 3.82 & 0.000 & .0953656 & .2959481 \\
\hline $1881-1886$ & .2207156 & .1035501 & 2.13 & 0.033 & .017761 & .4236701 \\
\hline $1886-1891$ & -.3215843 & .2210117 & -1.46 & 0.146 & -.7547592 & .1115906 \\
\hline Schools / 10 municip. & -.0243471 & .0091175 & -2.67 & 0.008 & -.0422171 & -.0064771 \\
\hline Rural pop / 1000 ha & -.0631654 & .0160716 & -3.93 & 0.000 & -.0946651 & -.0316656 \\
\hline Constant & .4306337 & .2342026 & 1.84 & 0.066 & -.0283949 & .8896623 \\
\hline
\end{tabular}


Bocquier \& Brée: Regional perspective on economic determinants of urban transition in $19^{\text {th }}$-century France

Table A-2: (Continued)

\begin{tabular}{|c|c|c|c|c|c|c|}
\hline & Coef. & Std. Err. & $z$ & $\mathrm{P}>|\mathrm{z}|$ & $\begin{array}{l}\text { [95\% Conf. Interval] } \\
\text { Lower bound }\end{array}$ & Upper bound \\
\hline \multicolumn{7}{|l|}{$\Delta$ reclassification } \\
\hline Cluster 1 1856-1861 & .0896898 & .2642186 & 0.34 & 0.734 & -.4281691 & .6075487 \\
\hline Cluster 2 1856-1861 & {$[R E F]$} & & & & & \\
\hline Cluster 3 1856-1861 & .3943766 & .2546289 & 1.55 & 0.121 & -.1046868 & .8934401 \\
\hline Cluster 4 1856-1861 & .8872359 & .55471 & 1.60 & 0.110 & -.1999758 & 1.974447 \\
\hline Cluster 1 1861-1866 & 1.094 & .5257926 & 2.08 & 0.037 & .0634657 & 2.124535 \\
\hline Cluster 2 1861-1866 & .8553898 & .5750227 & 1.49 & 0.137 & -.271634 & 1.982414 \\
\hline Cluster 3 1861-1866 & .9116329 & .5690643 & 1.60 & 0.109 & -.2037126 & 2.026978 \\
\hline Cluster 4 1861-1866 & 6727732 & .4705988 & 1.43 & 0.153 & -.2495835 & 1.59513 \\
\hline Cluster 1 1866-1872 & .5766592 & .4449643 & 1.30 & 0.195 & -.2954547 & 1.448773 \\
\hline Cluster 2 1866-1872 & .6750248 & .4419757 & 1.53 & 0.127 & -.1912317 & 1.541281 \\
\hline Cluster 3 1866-1872 & .7679259 & .4372718 & 1.76 & 0.079 & -.0891111 & 1.624963 \\
\hline Cluster 4 1866-1872 & .5194262 & .4402973 & 1.18 & 0.238 & -.3435407 & 1.382393 \\
\hline Cluster 1 1872-1881 & .9664033 & .5504798 & 1.76 & 0.079 & -.1125173 & 2.045324 \\
\hline Cluster 2 1872-1881 & .4709725 & .4970094 & 0.95 & 0.343 & -.503148 & 1.445093 \\
\hline Cluster 3 1872-1881 & .7794926 & .4605455 & 1.69 & 0.091 & -.1231601 & 1.682145 \\
\hline Cluster 4 1872-1881 & .5881766 & .4603025 & 1.28 & 0.201 & -.3139996 & 1.490353 \\
\hline Cluster 1 1881-1886 & 1.889066 & 1.006645 & 1.88 & 0.061 & -.0839214 & 3.862053 \\
\hline Cluster 2 1881-1886 & 1.392978 & .8710599 & 1.60 & 0.110 & -.3142685 & 3.100224 \\
\hline Cluster 3 1881-1886 & 1.818112 & .7697074 & 2.36 & 0.018 & .3095132 & 3.326711 \\
\hline Cluster 4 1881-1886 & 2.124597 & .668647 & 3.18 & 0.001 & .8140727 & 3.435121 \\
\hline Cluster 1 1886-1891 & -1.400426 & .731886 & -1.91 & 0.056 & -2.834896 & .0340447 \\
\hline Cluster 2 1886-1891 & .1635954 & .5028271 & 0.33 & 0.745 & -.8219276 & 1.149118 \\
\hline Cluster 3 1886-1891 & .1385355 & .4617036 & 0.30 & 0.764 & -.7663868 & 1.043458 \\
\hline Cluster 4 1886-1891 & .3708937 & .4574247 & 0.81 & 0.417 & -.5256421 & 1.26743 \\
\hline Percent Urban & .0126507 & .015347 & 0.82 & 0.410 & -.0174289 & .0427302 \\
\hline Percent Urban squared & -.0004012 & .0002842 & -1.41 & 0.158 & -.0009582 & .0001558 \\
\hline$\%$ Urb adjac counties & -.00061 & .0101362 & -0.06 & 0.952 & -.0204766 & .0192565 \\
\hline \multicolumn{7}{|l|}{ distance Paris } \\
\hline 1856-1861 & .0567002 & .0506774 & 1.12 & 0.263 & -.0426255 & .156026 \\
\hline $1861-1866$ & -.0328286 & .0431042 & -0.76 & 0.446 & -.1173113 & .0516542 \\
\hline $1866-1872$ & -.0017035 & .0251541 & -0.07 & 0.946 & -.0510047 & .0475976 \\
\hline $1872-1881$ & -.0205484 & .0349952 & -0.59 & 0.557 & -.0891378 & .0480409 \\
\hline $1881-1886$ & -.0774805 & .0968958 & -0.80 & 0.424 & -.2673929 & .1124318 \\
\hline 1886-1891 & .0116552 & .0421275 & 0.28 & 0.782 & -.0709131 & .0942236 \\
\hline \multicolumn{7}{|l|}{ distance big city } \\
\hline $1856-1861$ & .2514899 & .205376 & 1.22 & 0.221 & -.1510396 & .6540195 \\
\hline $1861-1866$ & -.1507422 & .1571349 & -0.96 & 0.337 & -.458721 & .1572366 \\
\hline $1866-1872$ & -.1950826 & .1001924 & -1.95 & 0.052 & -.3914561 & .0012909 \\
\hline $1872-1881$ & .0812389 & .1147508 & 0.71 & 0.479 & -.1436685 & .3061463 \\
\hline $1881-1886$ & -.1618614 & .2823407 & -0.57 & 0.566 & -.7152391 & .3915163 \\
\hline $1886-1891$ & .0614014 & .0898663 & 0.68 & 0.494 & -.1147334 & .2375362 \\
\hline Schools / 10 municip. & .0218989 & .0137166 & 1.60 & 0.110 & -.0049852 & .048783 \\
\hline Rural pop / 1000 ha & .0400915 & .0297525 & 1.35 & 0.178 & -.0182223 & .0984052 \\
\hline Constant & -1.162287 & .4323904 & -2.69 & 0.007 & -2.009756 & -.3148169 \\
\hline
\end{tabular}


Table A-2: (Continued)

\begin{tabular}{|c|c|c|c|c|c|c|}
\hline & Coef. & Std. Err. & $z$ & $\mathrm{P}>|\mathrm{z}|$ & $\begin{array}{l}\text { [95\% Conf. Interval] } \\
\text { Lower bound }\end{array}$ & Upper bound \\
\hline \multicolumn{7}{|l|}{$\Delta$ net migration } \\
\hline Cluster 1 1856-1861 & .9095267 & .5118097 & 1.78 & 0.076 & -.0936019 & 1.912655 \\
\hline Cluster 2 1856-1861 & [REF] & & & & & \\
\hline Cluster $31856-1861$ & -.0564019 & .6047695 & -0.09 & 0.926 & -1.241728 & 1.128925 \\
\hline Cluster 4 1856-1861 & .1347456 & .6324714 & 0.21 & 0.831 & -1.104876 & 1.374367 \\
\hline Cluster 1 1861-1866 & -2.227832 & 1.246123 & -1.79 & 0.074 & -4.670189 & .2145245 \\
\hline Cluster 2 1861-1866 & -2.042874 & 1.195334 & -1.71 & 0.087 & -4.385685 & .2999369 \\
\hline Cluster 3 1861-1866 & -1.693692 & 1.177979 & -1.44 & 0.150 & -4.002489 & .6151054 \\
\hline Cluster 4 1861-1866 & -2.339286 & 1.220463 & -1.92 & 0.055 & -4.731349 & .0527773 \\
\hline Cluster 1 1866-1872 & -.8011493 & 1.317607 & -0.61 & 0.543 & -3.383612 & 1.781313 \\
\hline Cluster 2 1866-1872 & -1.001319 & 1.237552 & -0.81 & 0.418 & -3.426876 & 1.424239 \\
\hline Cluster $31866-1872$ & -.9736172 & 1.194994 & -0.81 & 0.415 & -3.315763 & 1.368528 \\
\hline Cluster 4 1866-1872 & -1.11824 & 1.22422 & -0.91 & 0.361 & -3.517667 & 1.281186 \\
\hline Cluster 1 1872-1881 & -3.419126 & 2.001858 & -1.71 & 0.088 & -7.342697 & .5044439 \\
\hline Cluster 2 1872-1881 & -4.642348 & 1.767501 & -2.63 & 0.009 & -8.106587 & -1.17811 \\
\hline Cluster 3 1872-1881 & -3.598001 & 1.61871 & -2.22 & 0.026 & -6.770615 & -.4253873 \\
\hline Cluster 4 1872-1881 & -5.742294 & 2.236839 & -2.57 & 0.010 & -10.12642 & -1.35817 \\
\hline Cluster 1 1881-1886 & -2.839133 & 4.533051 & -0.63 & 0.531 & -11.72375 & 6.045484 \\
\hline Cluster 2 1881-1886 & -4.672846 & 3.899921 & -1.20 & 0.231 & -12.31655 & 2.970858 \\
\hline Cluster 3 1881-1886 & -4.275417 & 4.269766 & -1.00 & 0.317 & -12.644 & 4.093172 \\
\hline Cluster 4 1881-1886 & 1.944015 & 2.483502 & 0.78 & 0.434 & -2.92356 & 6.81159 \\
\hline Cluster 1 1886-1891 & -.8364938 & 3.366969 & -0.25 & 0.804 & -7.435633 & 5.762645 \\
\hline Cluster 2 1886-1891 & -.0911146 & 1.529541 & -0.06 & 0.952 & -3.088959 & 2.90673 \\
\hline Cluster 3 1886-1891 & -.2766608 & 1.529494 & -0.18 & 0.856 & -3.274413 & 2.721092 \\
\hline Cluster 4 1886-1891 & -.5059967 & 1.515864 & -0.33 & 0.739 & -3.477035 & 2.465042 \\
\hline Percent Urban & -.0602644 & .0686564 & -0.88 & 0.380 & -.1948285 & .0742997 \\
\hline Percent Urban squared & .0020079 & .0013938 & 1.44 & 0.150 & -.000724 & .0047398 \\
\hline$\%$ Urb adjac counties & .0112974 & .0496234 & 0.23 & 0.820 & -.0859627 & .1085575 \\
\hline \multicolumn{7}{|l|}{ distance Paris } \\
\hline 1856-1861 & -.0650265 & .1601493 & -0.41 & 0.685 & -.3789134 & .2488604 \\
\hline $1861-1866$ & .2452008 & .099339 & 2.47 & 0.014 & .0505 & .4399016 \\
\hline $1866-1872$ & -.0020779 & .1020498 & -0.02 & 0.984 & -.2020917 & .197936 \\
\hline $1872-1881$ & .2661869 & .1854035 & 1.44 & 0.151 & -.0971974 & .6295711 \\
\hline $1881-1886$ & .6326921 & .3023745 & 2.09 & 0.036 & .0400489 & 1.225335 \\
\hline 1886-1891 & -.0059577 & .1429847 & -0.04 & 0.967 & -.2862024 & .2742871 \\
\hline \multicolumn{7}{|l|}{ dist big city } \\
\hline 1856-1861 & -.5463065 & .4369868 & -1.25 & 0.211 & -1.402785 & .310172 \\
\hline $1861-1866$ & .3015861 & .3485097 & 0.87 & 0.387 & -.3814804 & .9846525 \\
\hline $1866-1872$ & .5393763 & .3271176 & 1.65 & 0.099 & -.1017624 & 1.180515 \\
\hline $1872-1881$ & 1.359529 & .4937819 & 2.75 & 0.006 & .3917347 & 2.327324 \\
\hline $1881-1886$ & 1.501224 & 1.865829 & 0.80 & 0.421 & -2.155734 & 5.158182 \\
\hline 1886-1891 & .2829676 & .4157035 & 0.68 & 0.496 & -.5317963 & 1.097732 \\
\hline Schools / 10 municip. & -.1129272 & .0847796 & -1.33 & 0.183 & -.2790922 & .0532377 \\
\hline Rural pop / 1000 ha & .1392512 & .119831 & 1.16 & 0.245 & -.0956133 & .3741157 \\
\hline constant & 3.265701 & 1.84683 & 1.77 & 0.077 & -.3540192 & 6.885421 \\
\hline
\end{tabular}


Bocquier \& Brée: Regional perspective on economic determinants of urban transition in $19^{\text {th }}$-century France

Table A-2: (Continued)

\begin{tabular}{|c|c|c|c|c|c|c|}
\hline & Coef. & Std. Err. & $z$ & $\mathrm{P}>|\mathrm{z}|$ & $\begin{array}{l}\text { [95\% Conf. Interval] } \\
\text { Lower bound }\end{array}$ & Upper bound \\
\hline \multicolumn{7}{|l|}{ Variance } \\
\hline $\operatorname{var}(\triangle \mathrm{CBR})$ & .2628566 & .0682096 & & & .1580658 & .4371194 \\
\hline $\operatorname{var}(\Delta \mathrm{CDR})$ & .2590221 & .0759554 & & & .1457911 & .4601956 \\
\hline $\operatorname{var}(\Delta$ reclass. $)$ & .8826424 & .1272297 & & & .6654068 & 1.170799 \\
\hline $\operatorname{var}(\Delta$ net migr.) & 12.35503 & 4.570043 & & & 5.983982 & 25.50924 \\
\hline \multicolumn{7}{|l|}{ Covariance } \\
\hline $\operatorname{cov}(\Delta \mathrm{CDR}, \Delta \mathrm{CBR})$ & -.2185164 & .0711843 & -3.07 & 0.002 & -.3580351 & -.0789978 \\
\hline $\operatorname{cov}(\Delta$ reclass.,$\Delta \mathrm{CBR})$ & -.0828209 & .0216875 & -3.82 & 0.000 & -.1253277 & -.0403142 \\
\hline $\operatorname{cov}(\Delta$ net mig., $\Delta \mathrm{CBR})$ & -.1625766 & .2689682 & -0.60 & 0.546 & -.6897447 & .3645914 \\
\hline $\operatorname{cov}(\Delta$ reclass.,$\Delta \mathrm{CDR})$ & .0800233 & .0201158 & 3.98 & 0.000 & .0405971 & .1194495 \\
\hline $\operatorname{cov}(\Delta$ net mig., $\Delta \mathrm{CDR})$ & .1563931 & .2996785 & 0.52 & 0.602 & -.4309661 & .7437522 \\
\hline $\operatorname{cov}(\Delta \text { net mig., } \Delta \text { recl. })^{\prime}$ & -.541254 & .2123695 & -2.55 & 0.011 & -.9574905 & -.1250175 \\
\hline
\end{tabular}


Table A-3: Generalized structural equation model without cluster effect ( $N=480$ periods, 80 counties)

\begin{tabular}{|c|c|c|c|c|c|c|}
\hline & \multirow[t]{2}{*}{ Coef. } & \multirow[t]{2}{*}{ Std. Err. } & \multirow[t]{2}{*}{ z } & \multirow[t]{2}{*}{$P>|z|$} & \multicolumn{2}{|c|}{ [95\% Conf. Interval] } \\
\hline & & & & & Lower bound & Upper bound \\
\hline \multicolumn{7}{|l|}{$\Delta$ Crude birth rate } \\
\hline $1861-1866$ & .0802828 & .200325 & 0.40 & 0.689 & -.3123469 & .4729126 \\
\hline $1866-1872$ & .0036615 & .2073413 & 0.02 & 0.986 & -.40272 & .4100429 \\
\hline $1872-1881$ & .6506405 & .3062067 & 2.12 & 0.034 & .0504864 & 1.250794 \\
\hline $1881-1886$ & .5763313 & .2864594 & 2.01 & 0.044 & .0148811 & 1.137781 \\
\hline $1886-1891$ & -.1284205 & .2384048 & -0.54 & 0.590 & -.5956854 & .3388443 \\
\hline Percent Urban & .0352096 & .0079156 & 4.45 & 0.000 & .0196954 & .0507239 \\
\hline Percent Urban squared & -.0004614 & .0001537 & -3.00 & 0.003 & -.0007627 & -.0001601 \\
\hline$\%$ Urb adjac counties & .0099794 & .0039521 & 2.53 & 0.012 & .0022334 & .0177253 \\
\hline \multicolumn{7}{|l|}{ distance Paris } \\
\hline $1856-1861$ & -.0298845 & .0239248 & -1.25 & 0.212 & -.0767762 & .0170073 \\
\hline $1861-1866$ & -.0348496 & .0203333 & -1.71 & 0.087 & -.0747021 & .0050029 \\
\hline $1866-1872$ & -.0305255 & .0213346 & -1.43 & 0.152 & -.0723404 & .0112895 \\
\hline $1872-1881$ & -.0799441 & .0246895 & -3.24 & 0.001 & -.1283346 & -.0315536 \\
\hline $1881-1886$ & -.0643052 & .0313216 & -2.05 & 0.040 & -.1256944 & -.002916 \\
\hline $1886-1891$ & -.0496033 & .0267 & -1.86 & 0.063 & -.1019343 & .0027277 \\
\hline \multicolumn{7}{|l|}{ dist big city } \\
\hline $1856-1861$ & .0417989 & .0718952 & 0.58 & 0.561 & -.0991131 & .1827108 \\
\hline $1861-1866$ & -.0211788 & .062822 & -0.34 & 0.736 & -.1443077 & .1019501 \\
\hline $1866-1872$ & -.0254385 & .0737306 & -0.35 & 0.730 & -.1699477 & .1190707 \\
\hline $1872-1881$ & -.2328033 & .1151049 & -2.02 & 0.043 & -.4584047 & -.007202 \\
\hline $1881-1886$ & -.2438922 & .1134914 & -2.15 & 0.032 & -.4663313 & -.0214532 \\
\hline $1886-1891$ & .2013198 & .1786287 & 1.13 & 0.260 & -.1487861 & .5514256 \\
\hline Schools / 10 municip. & .0169387 & .0095468 & 1.77 & 0.076 & -.0017727 & .0356502 \\
\hline Rural pop / 1000 ha & .0516421 & .0214598 & 2.41 & 0.016 & .0095816 & .0937026 \\
\hline constant & -1.348109 & .2826433 & -4.77 & 0.000 & -1.902079 & -.7941381 \\
\hline
\end{tabular}


Bocquier \& Brée: Regional perspective on economic determinants of urban transition in $19^{\text {th }}$-century France

Table A-3: (Continued)

\begin{tabular}{|c|c|c|c|c|c|c|}
\hline & \multirow[t]{2}{*}{ Coef. } & \multirow[t]{2}{*}{ Std. Err. } & \multirow[t]{2}{*}{ Z } & \multirow[t]{2}{*}{$P>|z|$} & \multicolumn{2}{|c|}{ [95\% Conf. Interval] } \\
\hline & & & & & Lower bound & Upper bound \\
\hline \multicolumn{7}{|l|}{$\Delta$ Crude death rate } \\
\hline $1861-1866$ & .0008087 & .1938409 & 0.00 & 0.997 & -.3791125 & .3807299 \\
\hline $1866-1872$ & -.3478035 & .195143 & -1.78 & 0.075 & -.7302768 & .0346698 \\
\hline $1872-1881$ & -.5677878 & .2022023 & -2.81 & 0.005 & -.9640971 & -.1714786 \\
\hline $1881-1886$ & -.3983213 & .2252204 & -1.77 & 0.077 & -.8397453 & .0431026 \\
\hline $1886-1891$ & .165389 & .2361931 & 0.70 & 0.484 & -.2975409 & .628319 \\
\hline Percent Urban & -.0163903 & .0074932 & -2.19 & 0.029 & -.0310767 & -.001704 \\
\hline Percent Urban squared & .0003325 & .0001481 & 2.25 & 0.025 & .0000423 & .0006226 \\
\hline$\%$ Urb adiac counties & .0027376 & .0044043 & 0.62 & 0.534 & -.0058946 & .0113698 \\
\hline \multicolumn{7}{|l|}{ distance Paris } \\
\hline $1856-1861$ & .0496962 & .0232347 & 2.14 & 0.032 & .004157 & .0952353 \\
\hline $1861-1866$ & .0343319 & .0202208 & 1.70 & 0.090 & -.0053001 & .073964 \\
\hline $1866-1872$ & .0667664 & .0229003 & 2.92 & 0.004 & .0218825 & .1116502 \\
\hline $1872-1881$ & .0600538 & .0204036 & 2.94 & 0.003 & .0200636 & .100044 \\
\hline $1881-1886$ & .042967 & .0307922 & 1.40 & 0.163 & -.0173846 & .1033186 \\
\hline $1886-1891$ & .0534269 & .0284683 & 1.88 & 0.061 & -.0023701 & .1092238 \\
\hline \multicolumn{7}{|l|}{ dist big city } \\
\hline $1856-1861$ & .0211591 & .0641359 & 0.33 & 0.741 & -.1045449 & .1468631 \\
\hline $1861-1866$ & -.0241103 & .0570669 & -0.42 & 0.673 & -.1359593 & .0877387 \\
\hline $1866-1872$ & .0062369 & .0616422 & 0.10 & 0.919 & -.1145795 & .1270534 \\
\hline $1872-1881$ & .2059703 & .0561137 & 3.67 & 0.000 & .0959895 & .3159511 \\
\hline $1881-1886$ & .1767917 & .0854456 & 2.07 & 0.039 & .0093213 & .344262 \\
\hline $1886-1891$ & -.2792011 & .1787892 & -1.56 & 0.118 & -.6296215 & .0712193 \\
\hline Schools / 10 municip. & -.024598 & .0097537 & -2.52 & 0.012 & -.0437148 & -.0054811 \\
\hline Rural pop / 1000 ha & -.057371 & .0153052 & -3.75 & 0.000 & -.0873687 & -.0273733 \\
\hline constant & .6002329 & .2303353 & 2.61 & 0.009 & .1487839 & 1.051682 \\
\hline
\end{tabular}


Table A-3: (Continued)

\begin{tabular}{|c|c|c|c|c|c|c|}
\hline & \multirow[t]{2}{*}{ Coef. } & \multirow[t]{2}{*}{ Std. Err. } & \multirow[t]{2}{*}{ Z } & \multirow[t]{2}{*}{$P>|z|$} & \multicolumn{2}{|c|}{ [95\% Conf. Interval] } \\
\hline & & & & & Lower bound & Upper bound \\
\hline \multicolumn{7}{|l|}{$\Delta$ reclassification } \\
\hline $1861-1866$ & -.1816106 & .4856648 & -0.37 & 0.708 & -1.133496 & .7702749 \\
\hline $1866-1872$ & -.3154934 & .4292553 & -0.73 & 0.462 & -1.156818 & .5258315 \\
\hline $1872-1881$ & -.2277023 & .4458959 & -0.51 & 0.610 & -1.101642 & .6462376 \\
\hline $1881-1886$ & 1.239037 & .6276713 & 1.97 & 0.048 & .0088243 & 2.469251 \\
\hline $1886-1891$ & -.4421912 & .4226558 & -1.05 & 0.295 & -1.270581 & .3861989 \\
\hline Percent Urban & .0201752 & .0141167 & 1.43 & 0.153 & -.0074931 & .0478435 \\
\hline Percent Urban squared & -.0004548 & .0002688 & -1.69 & 0.091 & -.0009817 & .0000721 \\
\hline$\%$ Urb adjac counties & .0025329 & .010796 & 0.23 & 0.815 & -.0186269 & .0236927 \\
\hline \multicolumn{7}{|l|}{ distance Paris } \\
\hline $1856-1861$ & -.0137181 & .0612381 & -0.22 & 0.823 & -.1337425 & .1063063 \\
\hline $1861-1866$ & -.018809 & .0288293 & -0.65 & 0.514 & -.0753134 & .0376954 \\
\hline $1866-1872$ & -.0029477 & .0248861 & -0.12 & 0.906 & -.0517235 & .0458282 \\
\hline $1872-1881$ & -.0296413 & .0369078 & -0.80 & 0.422 & -.1019794 & .0426967 \\
\hline $1881-1886$ & -.1247485 & .0786739 & -1.59 & 0.113 & -.2789466 & .0294495 \\
\hline $1886-1891$ & -.0727726 & .0431767 & -1.69 & 0.092 & -.1573974 & .0118522 \\
\hline \multicolumn{7}{|l|}{ dist big city } \\
\hline $1856-1861$ & .0733577 & .1805655 & 0.41 & 0.685 & -.2805441 & .4272595 \\
\hline $1861-1866$ & -.0383295 & .154826 & -0.25 & 0.804 & -.3417829 & .2651239 \\
\hline $1866-1872$ & -.1132224 & .1037923 & -1.09 & 0.275 & -.3166516 & .0902067 \\
\hline $1872-1881$ & .1225058 & .091494 & 1.34 & 0.181 & -.0568193 & .3018308 \\
\hline $1881-1886$ & -.2962516 & .2071915 & -1.43 & 0.153 & -.7023394 & .1098362 \\
\hline $1886-1891$ & .0226967 & .0663765 & 0.34 & 0.732 & -.1073987 & .1527922 \\
\hline Schools / 10 municip. & .0239932 & .0143287 & 1.67 & 0.094 & -.0040904 & .0520769 \\
\hline Rural pop / 1000 ha & .0416974 & .0289327 & 1.44 & 0.150 & -.0150097 & .0984045 \\
\hline constant & -.5122941 & .4774731 & -1.07 & 0.283 & -1.448124 & .423536 \\
\hline
\end{tabular}


Bocquier \& Brée: Regional perspective on economic determinants of urban transition in $19^{\text {th }}$-century France

Table A-3: (Continued)

\begin{tabular}{|c|c|c|c|c|c|c|}
\hline & Coef. & Std. Err. & Z & $P>|z|$ & \multicolumn{2}{|c|}{ [95\% Conf. Interval] } \\
\hline & & & & & Lower bound & Upper bound \\
\hline \multicolumn{7}{|l|}{$\Delta$ net miaration } \\
\hline $1861-1866$ & -2.032154 & .9838491 & -2.07 & 0.039 & -3.960463 & -.1038453 \\
\hline $1866-1872$ & -1.084981 & 1.021202 & -1.06 & 0.288 & -3.086501 & .9165387 \\
\hline $1872-1881$ & -4.749943 & 1.816672 & -2.61 & 0.009 & -8.310554 & -1.189332 \\
\hline $1881-1886$ & 1.024182 & 2.924924 & 0.35 & 0.726 & -4.708564 & 6.756928 \\
\hline $1886-1891$ & -.382659 & 1.346312 & -0.28 & 0.776 & -3.021381 & 2.256063 \\
\hline Percent Urban & -.075051 & .0528992 & -1.42 & 0.156 & -.1787315 & .0286295 \\
\hline Percent Urban squared & .0023197 & .0014886 & 1.56 & 0.119 & -.0005979 & .0052374 \\
\hline$\%$ Urb adiac counties & .0164276 & .0426281 & 0.39 & 0.700 & -.0671219 & .0999772 \\
\hline \multicolumn{7}{|l|}{ distance Paris } \\
\hline $1856-1861$ & -.023546 & .1517947 & -0.16 & 0.877 & -.3210582 & .2739662 \\
\hline $1861-1866$ & .2426673 & .0799474 & 3.04 & 0.002 & .0859733 & .3993613 \\
\hline $1866-1872$ & .0093848 & .0803563 & 0.12 & 0.907 & -.1481107 & .1668802 \\
\hline $1872-1881$ & .280122 & .1491969 & 1.88 & 0.060 & -.0122987 & .5725426 \\
\hline $1881-1886$ & .249157 & .2847239 & 0.88 & 0.382 & -.3088915 & .8072055 \\
\hline $1886-1891$ & -.0201324 & .2671696 & -0.08 & 0.940 & -.5437753 & .5035104 \\
\hline \multicolumn{7}{|l|}{ dist big city } \\
\hline $1856-1861$ & -.4398391 & .4291822 & -1.02 & 0.305 & -1.281021 & .4013426 \\
\hline $1861-1866$ & .3804922 & .3731694 & 1.02 & 0.308 & -.3509064 & 1.111891 \\
\hline $1866-1872$ & .6584674 & .3803887 & 1.73 & 0.083 & -.0870808 & 1.404016 \\
\hline $1872-1881$ & 1.717644 & .6874387 & 2.50 & 0.012 & .3702885 & 3.064999 \\
\hline 1881-1886 & -.3542024 & 1.558297 & -0.23 & 0.820 & -3.408409 & 2.700004 \\
\hline $1886-1891$ & .3951956 & .4005158 & 0.99 & 0.324 & -.3898008 & 1.180192 \\
\hline Schools / 10 municip. & -.1106928 & .0837795 & -1.32 & 0.186 & -.2748975 & .0535119 \\
\hline Rural pop / 1000 ha & .171588 & .1451291 & 1.18 & 0.237 & -.11286 & .4560359 \\
\hline constant & 2.985664 & 2.047453 & 1.46 & 0.145 & -1.02727 & 6.998597 \\
\hline \multicolumn{7}{|l|}{ Variance } \\
\hline $\operatorname{var}(\Delta \mathrm{CBR})$ & .2797368 & .0787102 & & & .1611555 & .4855725 \\
\hline $\operatorname{var}(\Delta \mathrm{CDR})$ & .270369 & .0869939 & & & .1439045 & .5079716 \\
\hline $\operatorname{var}(\Delta$ reclass. $)$ & .9441862 & .1417476 & & & .7035088 & 1.267202 \\
\hline $\operatorname{var}(\Delta$ net migr. $)$ & 13.21119 & 5.028208 & & & 6.265744 & 27.85551 \\
\hline \multicolumn{7}{|l|}{ Covariance } \\
\hline $\operatorname{cov}(\Delta \mathrm{CDR}, \Delta \mathrm{CBR})$ & -.2276454 & .0819358 & -2.78 & 0.005 & -.3882367 & -.0670541 \\
\hline $\operatorname{cov}(\Delta$ reclass.,$\Delta \mathrm{CBR})$ & -.0765512 & .0217506 & -3.52 & 0.000 & -.1191816 & -.0339209 \\
\hline $\operatorname{cov}(\Delta$ net miq., $\Delta \mathrm{CBR})$ & -.1676173 & .3012708 & -0.56 & 0.578 & -.7580972 & .4228626 \\
\hline $\operatorname{cov}(\Delta$ reclass.,$\Delta \mathrm{CDR})$ & .0802635 & .0214219 & 3.75 & 0.000 & .0382774 & .1222495 \\
\hline $\operatorname{cov}(\Delta$ net mig., $\Delta \mathrm{CDR})$ & .1916576 & .3264378 & 0.59 & 0.557 & -.4481488 & .8314641 \\
\hline $\operatorname{cov}(\Delta$ net mig., $\Delta$ recl. $)$ & -.4626255 & .1946955 & -2.38 & 0.017 & -.8442217 & -.0810293 \\
\hline
\end{tabular}


Figure A-2: Urban-rural difference in direct natural, direct migration, reclassification, and total growth in Sweden (1820-1960)

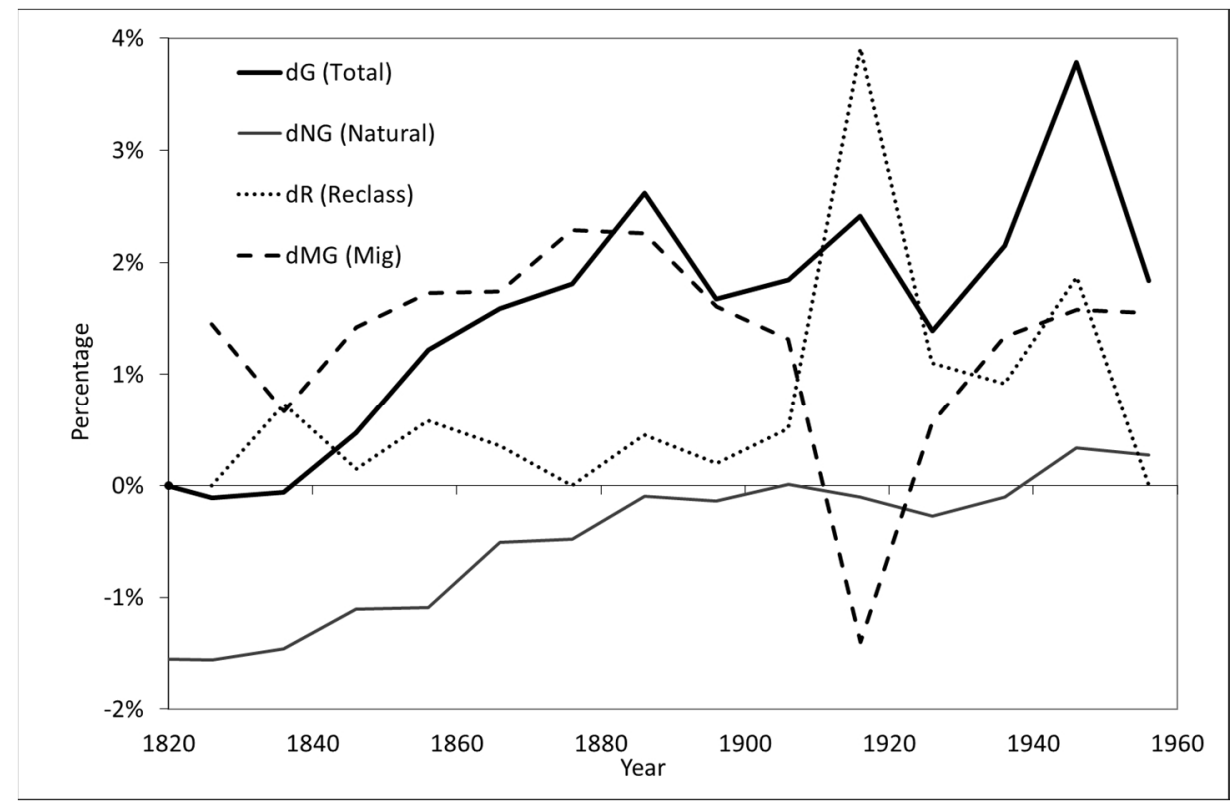

Source: Own computation using original crude birth and death estimates by urban and rural areas compiled by Dyson (2011) and historical series of population in cities and boroughs (Statistika Centralbyrån 1969: Table 12). 
Bocquier \& Brée: Regional perspective on economic determinants of urban transition in $19^{\text {th }}$-century France

Figure A-3: Urban-rural difference in direct natural, direct migration, reclassification, and total growth in Belgium (1844-1961)

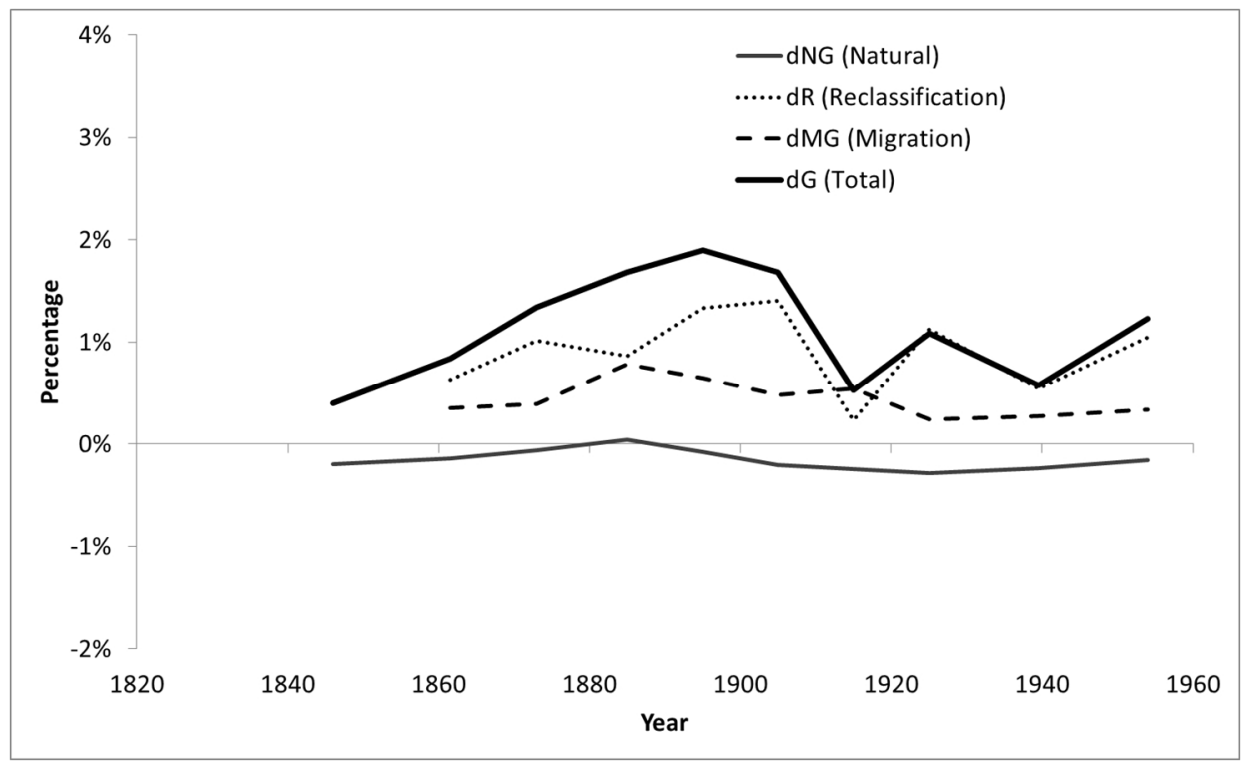

Source: Own computation using original crude birth, death, and reclassification estimates by urban and rural areas (Bocquier and Costa 2015). 